\title{
A quantitative study of modern pollen- vegetation relationships in southern Brazil's Araucaria forest
}

Article

Accepted Version

Creative Commons: Attribution-Noncommercial-No Derivative Works 4.0

Cardenas, M., Wilson, O., Schorn, L., Mayle, F. and Iriarte, J. (2019) A quantitative study of modern pollen-vegetation relationships in southern Brazil's Araucaria forest. Review of Palaeobotany and Palynology, 265. pp. 27-40. ISSN 00346667 doi: https://doi.org/10.1016/j.revpalbo.2019.03.003 Available at https://centaur.reading.ac.uk/83038/

It is advisable to refer to the publisher's version if you intend to cite from the work. See Guidance on citing.

To link to this article DOI: http://dx.doi.org/10.1016/j.revpalbo.2019.03.003

Publisher: Elsevier

All outputs in CentAUR are protected by Intellectual Property Rights law, including copyright law. Copyright and IPR is retained by the creators or other copyright holders. Terms and conditions for use of this material are defined in the End User Agreement.

www.reading.ac.uk/centaur 
Central Archive at the University of Reading

Reading's research outputs online 
1 A quantitative study of modern pollen-

2 vegetation relationships in southern Brazil's

3 Araucaria forest.

4 Macarena L. Cárdenas ${ }^{\mathrm{a}, \mathrm{b}}$, Oliver J. Wilson ${ }^{\mathrm{a} *}$, Lauri A. Schornc, Francis E. Mayle ${ }^{\mathrm{a}}$, José Iriarte ${ }^{\mathrm{d}}$

5 a School of Archaeology, Geography and Environmental Science (SAGES), University of Reading,

6 Whiteknights, P.O. Box 227, Reading RG6 6DW, Berkshire, United Kingdom

7 b Present address: Earthwatch Institute, Mayfield house, 256 Banbury Road, Oxford, OX2 7DE,

8 United Kingdom

9 ' Departamento e Engenharia Florestal, Universidade Regional de Blumenau, Brazil, 47-3221-6043,

$10 \quad 47-99973-4820$

11 d Department of Archaeology, University of Exeter, North Park Rd, Exeter, EX4 4QE, United Kingdom

$12 *$ Corresponding author: o.j.wilson@reading.ac.uk

13 Abstract

14 Southern Brazil's highland Araucaria forest is ancient, diverse and unique, but its future is under significant threat from $20^{\text {th }}$ Century habitat loss and $21^{\text {st }}$ Century climate change. Palaeoecological studies have revealed that it expanded rapidly over highland grasslands around 1,000 years ago, but whether this expansion was caused by human land use or climate change has been a topic of considerable debate. Discriminating between these potential drivers has so far not been possible 
with fossil pollen, however, as the palynological representation of floristic and structural

differences in Araucaria forest remains poorly understood. Here, we address this shortcoming using modern pollen rain from moss polsters and vegetation surveys in forest areas with minimal current human disturbance. We show that forest plots with evident structural differences lack consistent differences in their floristic composition and cannot be reliably distinguished by their pollen spectra. We quantify pollen-vegetation relationships for 27 key tree genera of Araucaria forest, showing that, despite significant intra-taxon variability, 22 of these are under-represented or absent in the pollen record. These palynologically under-represented and silent taxa include many of the forest's most ecologically important tree species, with only Araucaria, Lamanonia, Podocarpus, Myrsine and Clethra being more abundant in the pollen rain than vegetation. Our results suggest that subtle structural changes in Araucaria forest, as well as moderate to significant floristic changes, may not be clearly distinguished in fossil pollen records - an important limitation when attempting to identify past human and climatic impacts on Araucaria forest via pollen 32 analysis.

Key words: Araucaria forest, pollen, moss polsters, modern analogues, human impact

\section{Introduction}

\subsection{Rationale}

Disentangling the past effects of humans and climate on ecosystems requires a rigorous understanding of the vegetation changes that occurred, and how these are reflected in palaeoecological proxies. This is an important undertaking in Brazil's Araucaria forest (also known as Mixed Ombrophilous Forest), an ancient, highly diverse and threatened ecosystem in the country's southern highlands. Studies have charted changes in the distribution of Araucaria forest in relation to climatic variations since the late Pleistocene (Behling et al., 2004; Ledru et al., 2009), 
42 many finding rapid increases in its pollen abundance about 1,000 years ago which, in some sites, reached levels unprecedented for tens of thousands of years (Behling et al., 2004; Gu et al., 2017).

44 This marked expansion ca. 1000 years ago was much more drastic than the steady expansion of Araucaria forest over the previous few millennia, and has been attributed by some authors to ancient human land use, rather than climate change, due to the coincident expansion of the local southern proto-Jê culture (Bitencourt and Krauspenhar, 2006; dos Reis et al., 2014; Lauterjung et al., 2018; Noelli, 2000; Robinson et al., 2018), whose economy, spiritual beliefs and living space were closely linked to the forest (De Souza et al., 2016a; Iriarte et al., 2016; Iriarte and Behling, 2007).

Understanding the extent to which Araucaria forest's late-Holocene expansion can be attributed to humans versus climate change will improve our understanding of the ecosystem's responses to prevailing climatic conditions - a particularly important endeavour in the face of continuing anthropogenic climate change. With regional temperatures forecast to become warmer, and precipitation more variable, as this century progresses (Chou et al., 2014), the cold- and humiditydependent Araucaria forest is likely to contract (Bergamin, 2017; Wrege et al., 2009).

Understanding how this iconic forest responded to past variations in climate - and how humans may have altered this response - may help conservationists anticipate and ameliorate the effects of modern climatic changes upon its distribution. This is especially important as Araucaria forest cover was much reduced by the 20th Century logging boom in the states of Paraná, Santa Catarina and Rio Grande do Sul (Carvalho and Nodari, 2010), with remnants now covering just $12.6 \%$ of the biogeographic region it previously dominated (Ribeiro et al., 2009).

The main proxy used for reconstructing past dynamics of vegetation on the southern Brazilian 
which requires appropriate characterisation and quantification of modern pollen-vegetation relationships. This is currently poor for Brazil's Araucaria forest. Existing pollen-vegetation studies

67 (Behling et al., 2001; Garcia et al., 2004; Jeske-Pieruschka et al., 2010) are purely qualitative, identifying Araucaria forest's key indicator taxa but giving little insight into the degree to which the floristic composition or structure of these forests can be resolved palynologically. In this study, we address this shortcoming, presenting the first quantitative examination of the modern pollenvegetation relationship of Araucaria forest and its constituent taxa.

\subsection{Background}

Araucaria forest is home to over 1,500 species of plants, $6 \%$ of which are endemic to the Atlantic

Araucaria forest is found at the southern and south-eastern reaches of the Atlantic Forest biome, a global biodiversity hotspot (Colombo and Joly, 2010; Myers et al., 2000). It occupies the biome's high-altitude and low-temperature extreme niches (Neves et al., 2017; Oliveira-Filho et al., 2014), mostly occuring above 500m altitude (Hueck, 1953; Lacerda, 2016) in areas with high annual rainfall and climatic conditions classified as $\mathrm{Cfb}$ - humid subtropical oceanic climate, with temperate summers and no dry season (Alvares et al., 2013) - under the Köppen system (Higuchi et al., 2012; Hueck, 1953). At more southerly latitudes in Brazil, some apparently natural stands of Araucaria forest can also be found at elevations below 500m (Behling et al., 2016).

Forest biome (Neves et al., 2017), and is characterised by the dominance of the conifer Araucaria angustifolia in its canopy (Duarte et al., 2014; Leite and Klein, 1990; Meyer et al., 2013). This species has the third highest EDGE score (a metric which combines evolutionary distinctiveness and global endangerment) of all the world's gymnosperms (Forest et al., 2018), imperilled by logging and habitat loss which started in the late $19^{\text {th }}$ Century and reduced the forests' area by $97 \%$ within three generations (Carvalho and Nodari, 2010; Thomas, 2013). Other important arboreal species 
include Dicksonia sellowiana, Podocarpus sellowiana, Matayba elaeagnoides, Lithraea brasiliensis,

Clethra scabra, Ocotea porosa, and Prunus myrtifolia (Duarte et al., 2014; Meyer et al., 2013).

Araucaria forest is not floristically homogenous, however. Early studies differentiated eight types of Araucaria forest (Klein, 1978), and the ecosystem's mixture of tropical and temperate elements varies with longitude, altitude, temperature, river basin, and distance to other forest types (Duarte et al., 2014; Gonçalves and Souza, 2014; Higuchi et al., 2012; Klein, 1975; Oliveira-Filho et al., 2014; Sevegnani et al., 2016). At higher altitudes, under drier conditions and in areas of high fire (Gonçalves and Souza, 2014; Oliveira-Filho et al., 2014).

Fossil pollen records from the eastern edge of southern Brazil's highland plateau show that the area

frequencies and shallower soils, Araucaria forest forms mosaics with campos grasslands (Hueck, 1966; Müller et al., 2012; Oliveira-Filho et al., 2014), with other ecotones occurring with seasonally deciduous and dense ombrophilous forests at its western and eastern extents, respectively was dominated by campos at the Last Glacial Maximum, with Araucaria forest likely confined to river valleys (Behling, 2002; Behling et al., 2004; Leonhardt and Lorscheitter, 2010). These forests subsequently expanded slightly 4,000-3,000 years ago, and then rapidly 1,500-900 years ago (Behling, 1997a, 1995; Behling et al., 2004; Iriarte and Behling, 2007; Jeske-Pieruschka and Behling, 2012; Leonhardt and Lorscheitter, 2010; Silva and Anand, 2011), in some places replacing grasslands within a century (Behling et al., 2004; Iriarte and Behling, 2007).

These changes have typically been attributed to climate change (Rodrigues et al., 2016a). However, recent speleothem data (Bernal et al., 2016) show that, although the initial Araucaria forest expansion at 4,000 yr BP does correlate with an increase in rainfall, no subsequent climate change accompanies the later, more significant forest expansion at 1,500-900 yr BP (Robinson et al., 2018). This has led several authors to invoke humans as the most likely cause for this most recent, rapid 
expansion of Araucaria forest (Bitencourt and Krauspenhar, 2006; dos Reis et al., 2014; Iriarte and

112 Behling, 2007; Noelli, 2000), bolstered by evidence that, under natural conditions, expansion of

113 forest patches into campos grassland can be extremely slow (less than 100m in 4,000 years (Silva

114 and Anand, 2011)).

115 Before European arrival, the indigenous people of the highlands, the southern Jê, had lifestyles that were at least semi-sedentary and practised a mixed economy that combined the cultivation of

117 manioc (Manihot esculenta), maize (Zea mays), squash (Cucurbita sp.) and beans (Phaseolus sp.)

118 with hunting, fishing, and gathering forest and riverine resources (Corteletti et al., 2015; De Souza

119 et al., 2016b; Henry, 1964; Métraux, 1946; Noelli and De Souza, 2017). Araucaria angustifolia seeds, 120 known as pinhão, have long been a critical food source for the southern Jê (Corteletti et al., 2015; 121 Heineberg, 2014; Henry, 1964; Loponte et al., 2016; Métraux, 1946; Urban, 1985), with one group 122 traditionally defining a year as "one period with no pine nuts" (Henry, 1964, p. 68). Ethnographic studies of extant southern Jê groups have also highlighted the importance of Araucaria forest - and

A. angustifolia in particular - as a source of spiritual power and cultural identity (Fernandes and Piovezana, 2015; Haverroth, 1997; Hoffmann, 2011; Robinson et al., 2017; Silva, 2002).

126 Archaeological records show that the southern Jê flourished around 1,000 years ago (Iriarte et al., 127 2016, 2013; Noelli and De Souza, 2017; Robinson et al., 2018), as changes in domestic architecture 128 appeared (De Souza et al., 2016b), combining with the arrival of funerary mound-and-enclosure complexes (De Souza et al., 2016a; Iriarte et al., 2016) to form highly structured 'sacred landscapes' 130 (Iriarte et al., 2013) in the highlands. The temporal overlap of these changes with the most recent Araucaria forest expansion suggests that more available forest resources likely helped underpin the cultural changes (Iriarte and Behling, 2007), and there is some evidence that the southern Jê may in 
133 turn have helped expand the forest (dos Reis et al., 2014; Lauterjung et al., 2018; Robinson et al., 134 2018), though this has not yet been tested with fossil pollen data.

\subsection{Aims}

136 Quantitative studies of the relationships between present-day Araucaria forest and its constituent 137 pollen assemblages are needed to improve the level of ecological detail that can be extracted from 138 fossil pollen records, and thereby obtain a firmer basis for unravelling the relative roles of climate 139 change versus human land use in driving this threatened forest's long-term dynamics over the past 140 several millennia. We therefore conducted a study to quantitatively define the vegetation-pollen 141 relationships of Araucaria forest taxa. Specifically, we analysed floristic inventories from vegetation 142 plots, and collected their constituent pollen assemblages from moss polsters, to determine: 1.

143 whether structurally different Araucaria forest patches can be differentiated by their pollen 144 spectra, and 2. how the constituent species of these patches are represented in the modern pollen 145 rain.

\section{Methods}

\subsection{Study site}

$148 \quad$ [Insert Figure 1 here]

149 Figure 1: Map of forest plot locations; numbers refer to plot codes (see Table 1 below). Plot colours:

150 Cyan: riverine; Olive: slope; Black: rock outcrop; Purple: open understorey; Orange: closed 151 understorey; Red: disturbed.

152 The Reserva Particular do Patrimonio Natural (RPPN) Emilio Einsfeld Filho $\left(27^{\circ} 58^{\prime} 0.80^{\prime \prime} \mathrm{S}\right.$, $15350^{\circ} 49^{\prime} 20.03^{\prime \prime}$ W, $650-990$ m a.s.l.), managed by the Florestal Gateados company, is located in the 154 municipalities of Campo Belo do Sul and Capão Alto, southern Santa Catarina State, Brazil (Figure 
155 1). RPPN Emilio Einsfeld Filho is located on the plateau of the Serra Catarinense, a gently undulating 156 landscape. The reserve covers 6,329 hectares of native Araucaria forest patches within a wider 157 matrix of campos grassland, with the largest density of forest along rivers, valleys and slopes. 158 Forested areas have been protected from timber extraction since 1989 and cattle grazing since 1591993 (Zeller, 2010).

160 The climate of the area corresponds to Cfb in the Köppen classification: humid subtropical with 161 temperate summers and no dry season, but with occurrence of severe frosts (Alvares et al., 2013; 162 Formento et al., 2004; Zeller, 2010). Between 2005 and 2009 the reserve's average annual 163 temperature was $16^{\circ} \mathrm{C}$, with hottest months averaging $31^{\circ} \mathrm{C}$, coldest months averaging $6.5^{\circ} \mathrm{C}$ and a 164 lowest recorded temperature of $-12^{\circ} \mathrm{C}$; in this period annual precipitation varied between 1300 and $1652400 \mathrm{~mm}$, with an average of 129 rainy days a year (Zeller, 2010).

$166 \quad 2.2$ Field sampling

167 2.2.1 Vegetation survey

168 The native Araucaria forest at RPPN Emilio Einsfeld Filho has been subject to ecological studies for 169 the last 20 years, with permanent plots of $10 \times 50 \mathrm{~m}$ installed to perform floristic inventories and 170 study forest dynamics under distinct geographic conditions. Within each plot all trees with d.b.h. 171 (diameter at breast height) $\geq 10 \mathrm{~cm}$ have been recorded (Formento et al., 2004; Maçaneiro et al., 172 2018). Percentage abundances were calculated based upon all recorded stems surveyed within 173 each plot.

174 The sixteen plots used in this study are located within the oldest and least disturbed areas of forest 175 and incorporate the widest available range of vegetation form and physical setting (Table 1). Data on canopy openness, slope, animal disturbance, geographical feature associations and topographic position were collected during botanical surveys in 2015 , and the plots classified into six structural 
categories according to their dominant feature:

- slope: forest patches in areas with $>25 \%$ inclination

- rock outcrop: forest patches where rock outcrops cover $>20 \%$ of plot surface

- open understorey: forest with closed canopy and scarce understorey

- closed understorey: forest with closed canopy and dense understorey

- naturally disturbed: forest patches with evidence of ground disturbance by wild boars

\begin{tabular}{|c|c|c|c|}
\hline Plot ID & $\begin{array}{c}\text { Forest Plot } \\
\text { category }\end{array}$ & Coordinates & $\begin{array}{c}\text { Altitude } \\
\text { (a.s.l.) }\end{array}$ \\
\hline 114 & Slope & $\begin{array}{l}28^{\circ} 2 ' 34.70^{\prime \prime S}, \\
50^{\circ} 45^{\prime} 21.40^{\prime \prime} \mathrm{W}\end{array}$ & $780 \mathrm{~m}$ \\
\hline 118 & Slope & $\begin{array}{l}28^{\circ} 3^{\prime} 28.80^{\prime \prime S}, \\
50^{\circ} 45^{\prime} 45.80^{\prime \prime} \mathrm{W}\end{array}$ & $924 \mathrm{~m}$ \\
\hline 117 & $\begin{array}{l}\text { Rock } \\
\text { outcrop }\end{array}$ & $\begin{array}{l}28^{\circ} 3^{\prime} 0.10^{\prime \prime} \mathrm{S}, \\
50^{\circ} 45^{\prime} 16.50^{\prime \prime} \mathrm{W}\end{array}$ & $856 \mathrm{~m}$ \\
\hline 110 & Riverine & $\begin{array}{l}28^{\circ} 1 \text { 1'17.30"S, } \\
50^{\circ} 46^{\prime} 55.50^{\prime \prime} \mathrm{W}\end{array}$ & $721 \mathrm{~m}$ \\
\hline 136 & Riverine & $\begin{array}{l}28^{\circ} 1^{\prime} 55.50^{\prime \prime S}, \\
50^{\circ} 45^{\prime} 59.00^{\prime \prime} \mathrm{W}\end{array}$ & $740 \mathrm{~m}$ \\
\hline 151 & Riverine & $28^{\circ} 3^{\prime} 22.50^{\prime \prime} \mathrm{S}$ & $874 m$ \\
\hline
\end{tabular}




\begin{tabular}{|c|c|c|c|}
\hline & & $50^{\circ} 45^{\prime} 29.60^{\prime \prime} \mathrm{W}$ & \\
\hline 119 & $\begin{array}{l}\text { Open } \\
\text { understorey }\end{array}$ & $\begin{array}{l}28^{\circ} 3^{\prime} 16.80^{\prime \prime} \mathrm{S}, \\
50^{\circ} 45^{\prime} 51.70^{\prime \prime} \mathrm{W}\end{array}$ & $929 \mathrm{~m}$ \\
\hline 122 & $\begin{array}{l}\text { Open } \\
\text { understorey }\end{array}$ & $\begin{array}{l}28^{\circ} 2^{\prime} 59.00^{\prime \prime} \mathrm{S}, \\
50^{\circ} 46^{\prime} 28.10^{\prime \prime} \mathrm{W}\end{array}$ & $921 \mathrm{~m}$ \\
\hline 123 & $\begin{array}{l}\text { Open } \\
\text { understorey }\end{array}$ & $\begin{array}{l}28^{\circ} 3^{\prime} 4.10^{\prime \prime S}, \\
50^{\circ} 46^{\prime} 11.60^{\prime \prime} \mathrm{W}\end{array}$ & $935 \mathrm{~m}$ \\
\hline 142 & $\begin{array}{l}\text { Open } \\
\text { understorey }\end{array}$ & $\begin{array}{l}28^{\circ} 3^{\prime} 42.60^{\prime \prime} \mathrm{S}, \\
50^{\circ} 46^{\prime} 26.60^{\prime \prime} \mathrm{W}\end{array}$ & $922 \mathrm{~m}$ \\
\hline 144 & $\begin{array}{l}\text { Open } \\
\text { understorey }\end{array}$ & $\begin{array}{l}28^{\circ} 3^{\prime} 24.30^{\prime \prime S}, \\
50^{\circ} 46^{\prime} 21.50^{\prime \prime} \mathrm{W}\end{array}$ & $953 \mathrm{~m}$ \\
\hline 156 & Disturbed & $\begin{array}{l}28^{\circ} 4^{\prime} 29.00^{\prime \prime S}, \\
50^{\circ} 46^{\prime} 22.10^{\prime \prime} \mathrm{W}\end{array}$ & $850 m$ \\
\hline 157 & Disturbed & $\begin{array}{l}28^{\circ} 4^{\prime} 11.80^{\prime \prime} \mathrm{S}, \\
50^{\circ} 46^{\prime} 20.90^{\prime \prime} \mathrm{W}\end{array}$ & $851 \mathrm{~m}$ \\
\hline 159 & Disturbed & $\begin{array}{l}28^{\circ} 4 ' 21.60^{\prime \prime} \mathrm{S}, \\
50^{\circ} 45^{\prime} 53.60^{\prime \prime} \mathrm{W}\end{array}$ & $868 m$ \\
\hline 141 & $\begin{array}{l}\text { Closed } \\
\text { understorey }\end{array}$ & $\begin{array}{l}28^{\circ} 3^{\prime} 40.70^{\prime \prime} \mathrm{S}, \\
50^{\circ} 46^{\prime} 14.90^{\prime \prime} \mathrm{W}\end{array}$ & $931 \mathrm{~m}$ \\
\hline 149 & $\begin{array}{l}\text { Closed } \\
\text { understorey }\end{array}$ & $\begin{array}{l}28^{\circ} 3^{\prime} 53.50^{\prime \prime} \mathrm{S}, \\
50^{\circ} 45^{\prime} 39.20^{\prime \prime} \mathrm{W}\end{array}$ & $891 \mathrm{~m}$ \\
\hline
\end{tabular}


Table 1: The studied forest plots, their structural category, and the location and altitude of each transect's starting point.

\subsubsection{Modern pollen rain}

Using moss polsters to study modern pollen rain has been widely used and recognized as a reliable technique (Atanassova, 2007; Caseldine, 1989; Hicks, 1977; López-Sáez et al., 2010; Pardoe, 2006; Pardoe et al., 2010; Tonkov et al., 2001). Moss polsters can collect several years' pollen (Pardoe et al., 2010), occur naturally within the forest on different substrates and at varied heights (allowing for effective capture of pollen rain) and do not need to be installed and managed before analysis (Hicks, 1985). Moss polsters were gathered every $10 \mathrm{~m}$ along the $50 \mathrm{~m}$ length of each forest inventory plot surveyed. At each collection point, polsters were obtained from ground level (including rocks), chest height $(1.20 \mathrm{~m})$ and overhead $(1.80 \mathrm{~m})$. The samples for each point of collection were mixed to form one homogeneous sample for each plot (following Pardoe et al., 2010), placed in a labelled, sealed plastic bag, and stored at $4^{\circ} \mathrm{C}$ to preserve the material.

\subsection{Laboratory methods}

Subsamples of $1 \mathrm{~cm}^{3}$ were extracted from each homogenised sample for pollen processing. Each subsample was centrifuged, washed with distilled water, centrifuged again, then treated with $10 \%$ $\mathrm{NaOH}$ and put in a hot-water bath to deflocculate the organics. Afterwards, acetolysis was carried out in the samples to dissolve cellulose material (Faegri and Iversen, 1989).

Samples were mounted on slides in silicone oil and counted at $400 \times$ and $1000 \times$ magnification using a Leica DME binocular microscope. Samples were counted to a minimum of 300 terrestrial pollen grains. Aquatic taxa and spores were also counted as is standard practice, but were excluded from the total terrestrial pollen (TTP) sum; non-native species (e.g. pine from recent plantations surrounding the reserve) were also excluded from the TTP sum. For pollen determination, the 
reference collection of the Tropical Palaeoecology Research Group of the University of Reading was used, along with several pollen atlases - Colinvaux et al. (1999), Hooghiemstra (1984), Roubik and Moreno (1991), Behling (1993) - and the online Neotropical Pollen Key (Bush and Weng, 2007).

Diagrams of vegetation and pollen abundance were made using C2 v.1.7.7 (Juggins, 2016).

\subsection{Data analysis}

\subsubsection{Vegetation data processing}

214 Analysis of each plot's floristic inventory data used percentage abundance (relative to the total number of individual trees counted) and relative coverage value (RCV). RCV (expressed as a percentage) indicates the importance of a species within a forest plot, taking into account its

217 individuals' density and dominance.

$$
R C V i=\frac{(R D o i+R D e n i)}{\sum(R D o+R D e n)} * 100
$$

219 RCVi: Relative Coverage Value for species i (\%)

220 RDoi: Relative dominance for species i (basal area $\left(\mathrm{m}^{2}\right)$ per hectare)

221 RDeni: Relative density for species i (number of individuals per hectare)

222 RDo: Relative dominance for all species $\left(\mathrm{m}^{2} / \mathrm{ha}\right)$

223 RDen: Relative density for all species ( $\mathrm{n} / \mathrm{ha}$ )

\section{$224 \quad$ 2.4.2 Statistical analysis of vegetation and pollen data}

225 To investigate the extent to which structural differences between plots are reflected in their

vegetation composition and pollen rain, we conducted cluster and Detrended Correspondence

227 Analysis (DCA) multivariate analyses using PAST (Hammer et al., 2001) v.3.19 (2018). Raw floristic

228 inventory and pollen data were normalised using natural logarithm before running the analyses.

229 Only taxa with abundance $\geq 2 \%$ in two or more plots were considered for cluster and multivariate 
analysis.

231 Cluster analysis was run with hierarchical clustering using the Unweighted Pair Group Method 232 (UPGM) algorithm, which iteratively joins clusters based on the average distance between all 233 members of the groups (Kent and Coker, 1992; Legendre et al., 2012). The measure of similarity or 234 distance measurements between samples (forest plots) was calculated using Bray-Curtis index of 235 dissimilarity (Kent and Coker, 1992). The DCA uses the same algorithm as Decorana (Hill and Gauch, 236 1980), with modifications according to Oksanen and Minchin (1997). The DCA method was 237 preferred as it allows the identification of the ecological variances amongst the forest plots (Correa238 Metrio et al., 2014).

239 To enable direct comparisons between taxa in the vegetation and pollen rain, which were mostly 240 identified at different taxonomic levels, the vegetation-pollen analysis was performed at genus 241 level, with congeneric species combined for the analysis (Burn et al., 2010).

242 To quantify the vegetation-pollen relationships of taxa in this study area, we calculated mean $\mathrm{p} / \mathrm{v}$ 243 (pollen/vegetation) values (Burn et al., 2010; Gosling et al., 2009; Montade et al., 2016), which are 244 analogous to $R$ values (Davis, 1963). We calculate the $p / v$ value for taxon $i$ as:

$$
p / v_{i}=\frac{\text { Pollen abundance (\%) averaged over all plots }{ }_{i}}{\text { Vegetation abundance (\%) averaged over all plots }}
$$

246 Although more complex measures of pollen production exist (e.g. Parsons and Prentice, 1981;

247 Sugita, 2007a, 2007b), p/v values provide a straightforward and intuitive index of the relationship 248 between vegetation and pollen abundance and continue to be foundational for vegetation 249 reconstruction (Mrotzek et al., 2017).

250 To complement this metric and show the variability in pollen-vegetation relationships between plots, we also calculated a pollen-vegetation abundance differential for taxon $i$ : 
253 Plots where a taxon was absent from both the pollen rain and vegetation survey were not included 254 in calculations of mean differentials. $p / v$ values and abundance differentials could not be calculated 255 for herbaceous taxa as these were not included in the vegetation survey. Data were plotted using R 256 v.3.4.2 (R Core Team, 2017) and PAST (Hammer et al., 2001) v.3.19 (2018).

\subsection{Vegetation}

259 Across the 16 forest plots, 54 tree species with d.b.h. $\geq 10 \mathrm{~cm}$ were recorded, of which 33 had relative abundances of $2 \%$ or higher in at least two plots; the relative (percentage) abundance of these species within each plot is shown in Figure 2 . The most consistently present species were Lithraea brasiliensis (15 plots), Cinnamodendron dinisii (13 plots), Myrsine coriacea, Ocotea pulchella and Araucaria angustifolia (12 plots), undifferentiated Eugenia sp. (11 plots), and

Calyptranthes cf. concinna, Ilex theezans, Pera glabrata, Podocarpus lambertii and Zanthoxylum 265 kleinii (10 plots).

266 The taxa with the highest average abundance in the vegetation were L. brasiliensis (9.1\%),

Cinnamodendron dinisii (7.7\%), A. angustifolia (7.3\%), undifferentiated Eugenia sp. (6.7\%), 0 . pulchella (5.7\%), and Calyptranthes cf. concinna (5.0\%). Of the common taxa, L. brasiliensis had the highest maximum abundance (34.2\%), followed by Eugenia sp. (26.4\%), A. angustifolia (26.1\%), E. uniflora (25.7\%) and Cinnamodendron dinisii (24.1\%). Two less common species with high maximum

271 abundances were Matayba elaeagnoides (found in three plots, max. 35.6\%) and Nectandra 272 megapotamica (three plots, max. 28.6\%).

273 Generally, tree species that were more abundant also had higher relative coverage values (RCVs; 
Figure 3): the taxa with the highest RCVs averaged across all plots were L. brasiliensis (10.3\%), $A$.

275 angustifolia (10.0\%), O. pulchella (7.8\%), C. dinisii (6.1\%), Styrax leprosus (5.3\%) and undifferentiated Eugenia sp. (5.2\%). Some species were found in few plots, but had high RCVs where they were present: the less frequent species with the highest RCVs averaged across the plots in which they were found were M. elaeagnoides (15.6\%, four plots), Luehea divaricata $(9.2 \%$, three plots), N. megapotamica (9.0\%, three plots), Vernonanthura discolor (7.4\%, five plots), Sebastiania commersoniana (7.0\%, six plots), Prunus myrtifolia (5.7\%, six plots), Piptocarpha angustifolia (5.2\%, two plots), Myrceugenia sp. (5.1\%, five plots) and Myrsine umbellata (5.0\%, two plots).

\subsection{Pollen}

170 pollen and spore types were found in the 16 forest plots. Of these, 118 could be identified to family level, 95 of which could be refined to genus, one to species (Ilex theezans). We also assign species names to Araucaria angustifolia and Podocarpus lambertii because no other species of these genera occur in our study area. The plots' pollen spectra are summarised in Figure 4, where abundant and important taxa are shown.

Eight pollen types were found in all 16 plots: A. angustifolia, Asteraceae (others total), Eugenia type, 'cf Lithraea a (Anacardiaceae)', Myrsine, Poaceae, P. lambertii, and Pteridophyta. Additionally, Araceae pollen was found in 15 plots, and Lithraea, Vernonanthura-type and Calyptranthes-type in 14; Sebastiania and undifferentiated Myrtaceae pollen was found in 12 plots, and Clethra, I. theezans and Pteris each in 10 plots. Additionally, Alchornea pollen and Cyathea-type spores were found at very low levels (average abundance $0.27 \%$ and $0.2 \%$ respectively) in 11 plots, with Seneciotype (average $0.35 \%$ ) and Mimosa scabrella-type (average $0.25 \%$ ) present in 10 plots.

Myrsine pollen was the most abundant across all plots (averaging 19.5\%), followed by $A$. angustifolia (16.6\%), Pteridophyta (13.2\%), Podocarpus lambertii (7.9\%) and Poaceae (5.2\%). 
Eugenia-type, 'cf Lithraea a (Anacardiaceae)', Asteraceae (others total), Lamanonia, I. theezans,

Calyptranthes-type, Vernonanthura-type and Clethra pollen all had average abundances between

$2991 \%$ and $5 \%$.

$300 \quad$ [Insert Figure 2 here]

301 Figure 2: Relative abundance (\%) of selected tree species in the vegetation survey. Species included 302 in the cluster analysis and DCA are indicated with an asterisk.

$303 \quad$ [Insert Figure 3 here]

304 Figure 3: Relative Coverage Values (RCVs, \%) of selected tree species in the vegetation survey. 'Ave. 305 (all)' = sum of RCVs/total number of plots; 'Ave. (present)' = sum of RCVs/number of plots in which 306 taxon was present.

307 [Insert Figure 4 here]

308 Figure 4: Relative abundance (\%) of selected pollen types. Taxa included in the cluster analysis and 309 DCA are indicated with an asterisk

\subsection{Plot differentiation}

31133 taxa from the vegetation survey and 15 pollen types met the $2 \%$ abundance threshold for 312 inclusion in the plot differentiation analysis (see section 2.4.2); these are identified with asterisks in 313 the summary diagrams (Figures 2 and 4).

$314 \quad$ [Insert Figure 5 here]

315 Figure 5: Cluster analyses (left; $a, c$ ) and DCAs (right; b, d) of plots by vegetation (top; a, b) and 316 pollen (bottom; c, d) taxa found in $\geq 2$ plots at $\geq 2 \%$ abundance. In the DCAs, convex hulls are 317 delimited for structural categories containing three or more plots. Plot types are identified by 318 colour and two-letter code (op: open; cl: closed; ri: riverine; di: disturbed; ro: rock; sl: slope; see 
320 In the cluster analysis of vegetation data (Figure 5a), similarity scores range from $\sim 0.25$ to $>0.75$.

321 Two plot groupings that are somewhat structurally consistent can be highlighted. One such cluster 322 contains three of the five open-understorey plots (P119, P122 and P123) with the lone slope plot 323 P118 (similarity score $>0.65$ ); the other is the pairing of riverine plots P136 and P110 which, despite 324 having similarity scores $<0.6$ relative to each other, are together highly dissimilar to all other plots. 325 In the DCA of vegetation data (Figure 5b), most variation is explained on axis 1 (eigenvalue 0.3781 ), 326 with values ranging from -196 (Cyathea sp.) to 365 (Nectandra megapotamica). The majority of 327 sample plots are clustered between 0 and 143 on axis 1, with the riverine plots P136 (202) and P110 328 (255) more distinguished. The values on axis 2 (eigenvalue 0.1268) range from -337 (Sapium glandulosum) to 388 (Myrsine umbellata); sample plots are all clustered between 0 and 140 on this 330 axis.

331 In the pollen cluster analysis (Figure 5c), plots' similarity scores range from $\sim 0.5$ to $>0.85$. Two small 332 clusters dominated by open understorey forest plots were found: P122 and P123 (both open; 333 similarity $>0.7$ ), and P144 and P119 (both open) with the rocky forest plot P117 (similarity $>0.7$ ). 334 These two groupings are quite dissimilar from each other, however, and the cluster that contains them both also contains seven non-open plots, and excludes the final open plot (P142). In the DCA of pollen spectra (Figure 5d) axis 1 (eigenvalue 0.2454 ) ranges from -72 (Pteris) to 305 337 (Lamanonia), with 15 of the plots clustered between 0 and 119; P151 is located at 184 . The forest 338 plots are less well distinguished on axis 2 (eigenvalue 0.07194 ), sitting between values of 0 and 110 339 on an axis that ranges from -233 (Myrtaceae others total) and 426 (Clethra total).

\subsection{Vegetation-pollen relationships.}


(Myrceugenia, Nectandra, Ocotea and Piptocarpha) were present in the vegetation but with no identifiable pollen produced or preserved $(p / v=0)$, and one (Clethra) was frequent in the pollen record without being recorded in the vegetation survey (giving it a mathematically infinite $\mathrm{p} / \mathrm{v}$ value). Four other genera had higher average abundances for pollen than vegetation $(p / v>1)$, and 18 were more abundant in the vegetation than pollen $(p / v<1)-$ see Figure 6.

Of the taxa found in both pollen and vegetation datasets, the most over-represented genus is Lamanonia, followed by Podocarpus, Myrsine and Araucaria. In plot P151 Lamanonia was not recorded in the vegetation but its pollen made up $20.3 \%$ of the total; with this data point excluded from the average calculations, Lamanonia's $\mathrm{p} / \mathrm{v}$ value is 1.25 . The most under-represented genera found in the pollen rain are Cinnamodendron, Allophylus, Prunus, Styrax, Luehea and Zanthoxylum (p/v < 0.05); Casearia, Matayba, Pera and Lithraea also have $\mathrm{p} / \mathrm{v}$ scores $<0.1$. Calyptranthes, Campomanesia, Eugenia, Sapium, Sebastiania and Xylosma all have p/v values between 0.1 and 0.5. The pollen type 'cf Lithraea a (Anacardiaceae)' was three times more common than pollen that could be confidently identified to the Lithraea genus; assigning these grains to Lithraea changes the genus's p/v score from 0.09 to 0.39 .

[Insert Figure 6 here]

Figure 6: $p / v$ values of key genera of Araucaria forest in this study. Clethra has an infinitely high $\mathrm{p} / \mathrm{v}$ value; faint sections in the bars of Lamanonia and Lithraea reflect alternate calculations of their $\mathrm{p} / \mathrm{v}$ values (see section 3.4).

Between-plot variability in vegetation-pollen relationships is not well demonstrated by $\mathrm{p} / \mathrm{v}$ values, as their calculation requires a taxon to be present in both vegetation and pollen records for a plot. The only taxon for which this occurs in all plots is Eugenia, whose plot-specific $\mathrm{p} / \mathrm{v}$ scores varied between 0.04 (P141) and 2.26 (P122), with 14 plots having $\mathrm{p} / \mathrm{v}$ values $<1$. This variability is more 
evident with pollen-vegetation abundance differentials (Table 3 and Figure 7). Myrsine, Araucaria 366 and Podocarpus had the most positive mean values (all above $+5 \%$ ); Nectandra, Eugenia, Lithraea, 367 Cinnamodendron, Styrax, Ocotea, and Matayba had the most negative mean values (all below $-5 \%$ ).

368 Lithraea's mean differential changes to -5.52\% if 'cf Lithraea (Anacardiaceae)' pollen is included in 369 the calculation.

\begin{tabular}{|c|c|c|c|c|}
\hline Genus & Mean & Min & Max & Range (Max-Min) \\
\hline Allophylus & -4.13 & -8.57 & 0.20 & 8.77 \\
\hline Araucaria & +9.36 & -9.48 & 20.63 & 30.11 \\
\hline Calyptranthes & -3.44 & -17.06 & 1.09 & 18.15 \\
\hline Campomanesia & -2.08 & -5.71 & 0.81 & 6.52 \\
\hline Casearia & -4.17 & -13.84 & 0.45 & 14.29 \\
\hline Cinnamodendron & -8.08 & -24.14 & 0.44 & 24.57 \\
\hline Clethra & +1.76 & 0.37 & 6.68 & 6.31 \\
\hline Eugenia & -8.47 & -25.92 & 7.17 & 33.09 \\
\hline Ilex & -1.07 & -8.73 & 2.93 & 11.66 \\
\hline Lamanonia & +2.69 & -1.16 & 20.32 & 21.49 \\
\hline Lithraea & -8.25 & -32.56 & 0.26 & 32.82 \\
\hline Luehea & -4.89 & -8.89 & 0.18 & 9.07 \\
\hline Matayba & -6.29 & -34.14 & 0.36 & 34.50 \\
\hline Myrceugenia & -4.61 & -9.09 & -1.75 & 7.34 \\
\hline
\end{tabular}




\begin{tabular}{|l|l|l|l|l|}
\hline Myrsine & +13.88 & -3.05 & 55.75 & 58.80 \\
\hline Nectandra & -11.73 & -28.57 & -2.17 & 26.40 \\
\hline Ocotea & -7.25 & -16.36 & -1.75 & 14.61 \\
\hline Pera & -4.83 & -21.04 & 1.21 & 22.25 \\
\hline Piptocarpha & -3.02 & -4.29 & -1.75 & 2.53 \\
\hline Podocarpus & +5.78 & -5.73 & 19.24 & 24.97 \\
\hline Prunus & & & & \\
\hline Sapium & -3.21 & -6.82 & 0.23 & 7.04 \\
\hline Sebastiania & -4.35 & -25.85 & 0.55 & 26.40 \\
\hline Styrax & -1.27 & -5.05 & 0.44 & 5.49 \\
\hline Vernonanthura & -0.38 & -4.89 & 1.83 & 6.72 \\
\hline & -2.16 & -7.02 & 1.49 & 8.51 \\
\hline & & -22.86 & 0.45 & 23.31 \\
\hline & & & & \\
\hline
\end{tabular}

370 Table 3: Pollen-vegetation abundance differential values (\%) for key genera of Araucaria forest in 371 this study.

372 Myrsine had the most extreme positive values: $+55.75 \%$ (P114, slope), $+41.25 \%$ (P157, disturbed), $373+30.70 \%$ (P141, closed understorey), $+26.38 \%$ (P142, open understorey) and $+20.48 \%$ (P159, 374 disturbed). Values above $+20 \%$ also occurred twice for Araucaria $(+20.63 \%$ in P151, riverine, and $375+20.30 \%$ in P159, disturbed) and once for Lamanonia (+20.32\% in P151, riverine). Similarly negative 376 values (below -20\%) were more evenly spread among taxa, with two cases in Styrax $(-22.86 \%$ in 377 P122, open understorey, and $-20.00 \%$ in P141, closed understorey) and one each in Matayba (- 
$34.14 \%$ in $\mathrm{P} 136$, riverine), Lithraea (-32.56\% in P114, slope), Nectandra (-28.57\% in P110, riverine),

Eugenia (-25.92\% in P156, disturbed), Sebastiania (-25.85\% in P151, riverine), Cinnamodendron (24.14\% in P159, disturbed), and Pera (-21.04\% in P119, open understorey).

Figure 7: Pollen-vegetation abundance differentials (square-root transformed) for selected genera.

Positive values denote plots where a taxon's pollen was more abundant than its vegetation; negative values reflect vegetation being more abundant than pollen. Blank cells denote plots where a taxon was absent from both pollen and vegetation data.

The genus with the greatest difference between maximum and minimum abundance differentials is Myrsine, with wide variation (> 30\%) also found in Matayba, Eugenia, Lithraea and Araucaria; negative). However, few taxa (Araucaria, Eugenia, llex, Myrsine, Podocarpus) had differentials $>2 \%$ 392 in both positive and negative directions.

\subsection{Detecting structural differences in Araucaria forest} most important tree species (Schorn et al., 2012). Three of the predominant species in this study ( $A$. angustifolia, O. pulchella, P. lambertii), as well as others found at lower levels (Matayba elaeagnoides, Lamanonia ternata), are key indicator species (Gonçalves and Souza, 2014). Lithraea brasiliensis, the most common, abundant and dominant species in our sample plots, is the fifth 
most important tree across Santa Catarina's Araucaria forest, especially significant below $1200 \mathrm{~m}$ a.s.I (Meyer et al., 2013; Schorn et al., 2012).

The floristic composition of the plots is somewhat variable, with no pair of plots having a similarity score above 0.8 (Figure 5a), but this variability in composition does not generally reflect the structural differences between the plots. This can be seen in the cluster analysis (Figure 5a): three of the open understorey plots (P119, P122, P123) are clustered together along with the slope plot P118, but the remaining two open plots (P142 and P144) are far removed; the cluster that would include all five open plots would have 14 members. Similarly, the disturbed plots P157 and P159 are closely paired, but the cluster that would also include the third disturbed plot (P156) would encompass nine plots in total. The riverine plots $\mathrm{P} 110$ and $\mathrm{P} 136$ are distinct from the rest of the plots but cannot be grouped with the third member of the riverine group (P151) without including all sampled plots in the cluster.

This pattern is further shown in the DCA (Figure $5 b$ ), of which only axis 1 has an eigenvalue $>0.3$ (0.3781), which would be suggestive of ecological relevance (Peterson and Gale, 1991; Rezende et al., 2015). Here again P110 and P136 are the only plots that are clearly distinguished by their vegetation. Their floristic difference to the other studied plots may partly result from their location at the northern end of the studied area, $>1.5 \mathrm{~km}$ from the other plots. Their regeneration stage could also be an explanatory factor: these plots have the highest RCVs for Matayba elaeagnoides, as well as the highest recorded abundances of the pioneer Nectandra megapotamica, two of the three highest abundances of Allophylus edulis, and the presence of Sebastiania commersoniana, all of which are important taxa in regenerating Araucaria forest patches (Meyer et al., 2013; Schorn et al., 2012).

The most common and abundant tree pollen in our study sites came from Araucaria angustifolia, 
423 Myrtaceae (mainly Eugenia), Anacardiaceae cf Lithraea, Myrsine and Podocarpus, with Lithraea,

424 Vernonanthura-type, Sebastiania, Ilex and Clethra found in the majority of plots at generally low

425 abundances (Figure 4). Pteridophyte spores were both common and abundant, and Poaceae was

426 the most prevalent herbaceous pollen taxon, with Asteraceae and Araceae pollen also common but

427 less abundant. The sum of all herbaceous pollen varies from $5-20 \%$, averaging $10 \%-$ similar to the

$4285-15 \%$ found by Garcia et al. (2004) in a study of Araucaria forest peat deposits in Sao Paulo state,

429 but lower than the $24-60 \%$ found by Jeske-Pieruschka et al. (2010) in a forest patch surrounded by

430 campos grassland. The herbaceous pollen counts in the latter were likely increased by influx from

431 the grasslands surrounding the forest, and as a result of disturbance from grazing in the studied

432 forest patch (Jeske-Pieruschka et al., 2010).

433 The plots are less well differentiated by pollen than by their vegetation, as shown by their generally 434 higher cluster similarity scores (Figure $5 c$ ). As with the vegetation there are some potential pairings 435 of open understorey plots (P122 and P123; P119 and P144 with the rocky plot P117), but these are 436 quite distinct from each other - the cluster that would encompass all five open plots would only 437 exclude the riverine plot P151. No potential groupings in the pollen cluster analysis mirror clusters 438 of the plots' vegetation (Figure $5 \mathrm{a}, \mathrm{c}$ ), and there are no consistent groupings of structurally similar 439 plots. This is also seen in the DCA (Figure $5 d$ ), where the eigenvalue for axis $1(0.2454)$ may indicate 440 the separation is not ecologically relevant (Peterson and Gale, 1991; Rezende et al., 2015). Here, as 441 in the cluster analysis, the only plot that is clearly distinguished is P151, due in large part to its 442 exceptionally high abundance of Lamanonia pollen.

443 These results show that the notable structural differences between the different forest plot 444 categories are not echoed in the composition of their woody taxa. Since there are no consistent 445 floristic differences between plot types, it is unsurprising that these structural differences cannot be 
detected by their pollen signals - especially as pollen's sensitivity is affected by relatively coarse taxonomic resolution and differential pollen production and preservation between taxa.

\subsection{Vegetation-pollen relationships}

449 The pollen records of the studied forest plots did not consistently reflect large variations in a 450 taxon's abundance in the vegetation (Figure $6 \&$ 7). L. brasiliensis, for example, makes up $2.9 \%$ of 451 the vegetation in P110 and 34.1\% in P114 (Figure 2), but Lithraea pollen is equally abundant in each 452 plot (1.6\%) (Figure 4); its abundance in the vegetation is intermediate in P117 (10.9\%) and P118 $453(12.3 \%)$ but its pollen makes up just $0.9 \%$ and $1.0 \%$ of those plot totals, respectively. This variability 454 in vegetation-pollen relationships can also be illustrated with Myrsine: its pollen made up more 455 than half of all counted grains (55.8\%) in P114, despite no individuals from the genus being 456 recorded in the vegetation survey; it was also significantly over-represented in P157 (pollen 457 abundance $43.4 \%$, vegetation abundance $2.2 \%)$, but proportionately represented in P119 (17.3\% of 458 the pollen; $17.0 \%$ of the vegetation) and under-represented in P118 (5.7\% of the pollen, $8.8 \%$ of the 459 vegetation).

However, general patterns of over- or under-representation of each taxon in the pollen record could be determined - only Araucaria, Eugenia, Ilex, Myrsine and Podocarpus had both positive and negative abundance differentials above $2 \%$ (Table 3). The majority (22 of 27) of the arboreal genera examined were under-represented in the pollen record ( $p / v$ values $<1$; Figure 6$)$, with four (Myrceugenia, Nectandra, Ocotea and Piptocarpha) being palynologically silent. These underrepresented taxa include many of the most abundant tree species in the plots, as well as some of the most ecologically important taxa in Araucaria forest (Lithraea, Matayba, Cinnamodendron, 467 Ocotea, Prunus and Nectandra) (Sevegnani et al., 2013). The highest $\mathrm{p} / \mathrm{v}$ value among these key genera is Lithraea's 0.09 (i.e. less than one tenth as abundant in the pollen record as in the 
vegetation), and no pollen which could be reliably identified as Ocotea or Nectandra was counted

470 at all.

471 Under-representation in the pollen record is common in the Neotropics (Bush, 1995; Bush and 472 Rivera, 1998; Gosling et al., 2009; Haselhorst et al., 2013). This is partly due to the relative rarity of 473 anemophilous plants - generally the most over-represented taxa - in tropical forests, although 474 entomophilous plants are less under-represented in tropical pollen spectra than in temperate 475 regions (Bush, 1995; Viera et al., 2012; Whitehead, 1983). Our results fit this general pattern: of the 476 under-represented taxa in our study, Nectandra and Ocotea are pollinated by thrips (Thysanoptera) 477 (Danieli-Silva and Varassin, 2013; Souza and Moscheta, 2000), and Lithraea, llex, Matayba, Prunus, 478 Eugenia and Cinnamodendron depend on bees and other small insects (de Deus et al., 2014; Hermes and Köhler, 2006; Imperatriz-Fonseca et al., 1989; Montalva et al., 2011; Tomlinson, 1974; Wilms et al., 1997). Additionally, Ocotea pollen is fragile, with a thin exine that means it preserves poorly (Behling, 1993). By contrast, the over-represented taxa Araucaria (Bittencourt and Sebbenn, 2008, 2007) and Podocarpus (Midgley, 1989; Negash, 2003; Wilson and Owens, 1999) are anemophilous, as are South American members of Myrsine (Albuquerque et al., 2013; Otegui and Cocucci, 1999), and therefore produce abundant pollen.

Lamanonia was over-represented in the pollen record $(p / v 5.44 ; 1.25$ when excluding P151) despite being insect-pollinated (de Deus et al., 2014; Hermes and Köhler, 2006; Wilms et al., 1997). Its relative abundance of pollen in this study may be explained by its mass-flowering habit (Hermes and Köhler, 2006), so it is possible that Lamanonia's pollen-vegetation relationship varies significantly year-on-year. Clethra is another entomophilous taxon (Freitas and Sazima, 2006) with over-represented pollen in this study: its pollen was found in 10 of the 16 plots at an average abundance of $1.10 \%(0.37-4.58 \%)$, but no individuals were recorded in the vegetation (Figure 2) 
despite C. scabra being the third most important tree species in Araucaria forest (Schorn et al., 2012). Given Clethra pollen is not adapted for long-distance travel, it is unlikely to have originated outside the plots; potentially, individuals from this genus were present but too small to be included in the survey (i.e. d.b.h. $<10 \mathrm{~cm}$ ), making it difficult to make a true assessment of the taxon's pollen-vegetation relationship.

\subsection{Implications for palaeoecology}

Our findings have important implications for the interpretation of fossil pollen records. Many of the key taxa used to reconstruct past Araucaria forest dynamics were identified palynologically in this study, but two were largely missing. Pollen from Mimosa scabrella and Weinmannia is commonly cited as evidence of Araucaria forest (Behling, 1997a, 1995; Behling et al., 2004; Leonhardt and Lorscheitter, 2010) but M. scabrella pollen was not abundant (present in 10 of the 16 plots, maximum abundance $0.89 \%$ ) and Weinmannia pollen was absent; neither species was recorded in the vegetation survey. M. scabrella is a species which is especially encouraged by anthropogenic forest disturbance, so its absence here may be connected to the relatively long time since the last anthropogenic disturbance of our studied plots. Moreover, both taxa (especially Weinmannia) are much more floristically important at elevations above 1,200 m a.s.l. (Sevegnani et al., 2013) so their absence here is unsurprising, and highlights the biases of existing palaeoecological studies towards high-altitude regions along the eastern edge of the highland plateau (Behling, 2007, 1997a, 1995; Behling et al., 2004; Jeske-Pieruschka et al., 2013; Leonhardt and Lorscheitter, 2010; Scherer and Lorscheitter, 2014).

The geographical bias of existing studies can further be seen in the classifications proposed by Rodrigues et al. (2016b) for distinguishing woodland types in southern Brazil based on pollen spectra. Although our sites (721-953 m a.s.l.) have vegetation which is most similar to that in the 
'Iow Poaceae subtropical forest' (LPSF) category (Behling et al., 2004; Behling and de Oliveira, 2018; Jeske-Pieruschka et al., 2013; Jeske-Pieruschka and Behling, 2012), they are excluded from this group due to their absence of Weinmannia pollen. Instead, our plots would likely be included in the disparate 'low Poaceae subtropical-tropical' (LPST) group, along with two sites in Santa Catarina's coastal tropical forest (9-10 m a.s.I.) (Behling, 1997b, 1995), one in northern Argentina at the westernmost limit of Araucaria forest taxa (604 m a.s.I.) (Gessert et al., 2011), and another at low altitude in south-central Rio Grande do Sul (176 m a.s.I.) (Santa Mônica, unpublished, cited in Rodrigues et al., 2016b) . The significant altitudinal, geographical and floristic differences between

523 these sites suggests LPST may not be a true grouping, and that the classification of southern Brazil's 524 forests by their pollen spectra will improve as more westerly plateau sites, with different 525 assemblages of Araucaria forest, are studied.

Most of the taxa widely used in palaeoecological studies were here found to be over-represented in the pollen record (Araucaria, Myrsine, Podocarpus, Lamanonia) or under-represented but very abundant in the vegetation (Myrtaceae, such as Eugenia and Calyptranthes which are rarely distinguished to genus in fossil pollen). Fossil Lithraea pollen is quite often identified (Behling, 2007; Behling et al., 2016, 2005; Gessert et al., 2011) or grouped with Schinus (Behling, 1997b, 1997a; Behling et al., 2004; Jeske-Pieruschka et al., 2010) but rarely treated as important (but see Behling, 1997a; Gessert et al., 2011); given the floristic importance of L. brasiliensis (Meyer et al., 2013; abundant than vegetation on average), the presence and dynamics of Lithraea pollen may warrant more detailed examination in future studies. Lithraea is one of several key Araucaria forest taxa we have shown to be either significantly under-represented (Matayba, Cinnamodendron, Prunus) or absent (Ocotea, Nectandra) in the pollen record, even when quite abundant in the vegetation. This 
pollen, highlighting a potentially important limitation of pollen as a palaeoecological proxy for determining this ecosystem's responses to past millennial-scale human land use and climate changes.

542 The importance of fossil pollen's limited sensitivity to compositional changes in Araucaria forest is 543 reinforced when considering that structural differences between plots were not clearly reflected in 544 their pollen signals. Although the plots had notably different structural characteristics to one 545 another, this was only weakly echoed in the floristic composition of their arboreal component, and 546 even less so in their pollen spectra, which were more similar to each other than the vegetation. This 547 implies that pollen records may not clearly detect structural changes in Araucaria forest, especially 548 when these are not accompanied by significant or long-term alterations in floristic composition. 549 Further investigations of the sensitivity of pollen rain to larger-scale changes in composition and 550 structure of Araucaria forest might involve integration with the state-wide plot network of the 551 Santa Catarina forest floristic inventory (Vibrans et al., 2010) or palynological examination of forest 552 fragments with relatively intense present human land use, such as caívas, faxinais or ervais (Fichino 553 et al., 2017; Mello and Peroni, 2015; Reis et al., 2018). Such research would aid the interpretation 554 of fossil pollen records which do show significant changes with climatic changes and human land 555 use (e.g. Behling et al., 2004), permitting shifts in pollen composition to be more accurately related 556 to changes in the vegetation.

557 The difficulty of detecting structural and compositional changes in Araucaria forest with pollen 558 records has implications for the reconstruction of past human impacts on the forest. Before 559 European arrival, the indigenous southern Jê people lived in semi-subterranean dwellings in the 560 forest, practising swidden cultivation and exploiting Araucaria angustifolia nuts and Myrtaceae 561 fruits (Corteletti, 2012; Corteletti et al., 2015; dos Reis et al., 2014; Iriarte and Behling, 2007). It has 
been suggested that their lifestyles helped to spread Araucaria forest more quickly than natural drivers, such as climate change, and even beyond the forest's natural limits (Bitencourt and Krauspenhar, 2006; Iriarte and Behling, 2007; Lauterjung et al., 2018; Noelli, 2000; Robinson et al., 2018), but our findings raise the question of whether, and how, more subtle impacts within the

566 forest - especially structural and compositional changes - would be represented in fossil pollen sedimentary archives. There is significant ongoing debate over the extent to which pre-Columbian peoples altered the floristic composition of Amazonian forests (Barlow et al., 2012; Levis et al., 2018, 2017; McMichael et al., 2017; Shepard and Ramirez, 2011) and the limitations of fossil pollen

570 analysis in identifying such impacts are well known (e.g. Carson et al., 2016), with recent

571 simulations showing that pollen sites in tropical forest-grassland mosaics (like those between

572 Araucaria forest and campos grasslands) may be insensitive to large changes in forest cover

573 (Whitney et al., 2019). The forest plots in our study have been free of human disturbance for

574 several decades, so their present condition is unlikely to mirror the full range of southern Jê land use. Nevertheless, our findings highlight potential limitations of pollen analysis as a tool for investigating and reconstructing the role of the southern Jê in shaping the Araucaria forest's

577 floristic composition and structure - the absence of evidence of human impacts may not equate to 578 evidence of their absence.

\section{Conclusions}

In this study, the pollen rain from 16 structurally different Araucaria forest plots has been characterised and compared with floristic inventory data, and 27 tree genera have had their vegetation-pollen relationships quantified.

Our results show that the structurally different plots do not exhibit consistent differences in the floristic composition of their tree taxa. Correspondingly, their structural differences cannot be 
clearly detected in their pollen rain, with pollen spectra more similar than vegetation between plots.

On average, the most abundant tree species in the plots are Lithraea brasiliensis, Cinnamodendron dinisii, Araucaria angustifolia, Eugenia sp., Ocotea pulchella and Calyptranthes cf. concinna, representing the typical composition of Araucaria forest at this altitude. As well as these, Styrax leprosus has a high average relative coverage value (RCV) across all plots, and species including Matayba elaeagnoides, Nectandra megapotamica, Vernonanthura discolor, Prunus myrtifolia, Piptocarpha angustifolia, Myrceugenia sp. and Myrsine umbellata have high RCVs in the (relatively few) plots in which they occur. The modern pollen rain of Araucaria forest in our study area (720$920 \mathrm{~m}$ a.s.I.) is characterised by Myrsine (19.5\%), A. angustifolia (16.6\%), Pteridophyta (13.2\%), Podocarpus lambertii (7.9\%) and Poaceae (5.2\%), along with Eugenia-type, Anacardiaceae cf. Lithraea, Asteraceae (others), Lamanonia, Ilex theezans, Calyptranthes-type, Vernonanthura-type and Clethra at lower abundance.

Vegetation-pollen relationships vary between plots but general patterns of over- or underrepresentation could be identified for the majority of taxa. Araucaria, Lamanonia, Podocarpus, and Myrsine are over-represented in the pollen record (average $\mathrm{p} / \mathrm{v}>1$ ), and Clethra pollen was frequently identified but the genus is absent from the vegetation survey. All of the other 22 genera analysed are under-represented, with Myrceugenia, Nectandra, Ocotea and Piptocarpha palynologically silent.

The palynological under-representation of ecologically key Araucaria forest taxa and the lack of clear differentiation of structural differences in the forest's pollen spectra have important implications for the interpretation of fossil pollen records, highlighting the challenges of resolving past human impacts and ecological changes within Araucaria forest using this proxy. This 
quantitative analysis of vegetation-pollen relationships for key Araucaria forest taxa is a key tool for interpreting fossil pollen records and understanding past vegetation dynamics on the highlands of southern Brazil.

\section{Author contributions}

MLC and FEM conceived the study; MLC collected moss polsters; MLC and LAS collected vegetation survey data; MLC performed pollen analysis and counting; MLC and OJW analysed the data and interpreted the results; OJW, MLC and FEM drafted the manuscript; all authors commented on the manuscript before submission.

\section{Acknowledgements}

This study was funded by an AHRC-FAPESP research grant entitled 'Je Landscapes of southern Brazil: Ecology, History and Power in a transitional landscape during the Late Holocene' (AH/K004212/1) to JI and FEM, with MLC as appointed PDRA with FEM; OJW was funded by a University of Reading Graduate Teaching Assistant PhD studentship. The authors thank the Florestal Gateados Company for permission to conduct this research on their property; Museu Botânico Municipal of Curitiba for providing key herbarium samples for modern pollen references; Alyne Ruggiero and Alvaro Cortes for fieldwork assistance; Professor Hermann Behling for assistance with pollen identification; Dr John Carson for constructive comments in the early stages of the study; and Dr Mark Robinson for early editing support.

\section{References}

Albuquerque, A.A.E., de Lima, H.A., Gonçalves-Esteves, V., Benevides, C.R., Rodarte, A.T.A., 2013. Myrsine parvifolia (Primulaceae) in sandy coastal plains marginal to Atlantic rainforest: a case of pollination by wind or by both wind and insects? Brazilian J. Bot. 36, 65-73. 
631 Alvares, C.A., Stape, J.L., Sentelhas, P.C., De Moraes Gonçalves, J.L., Sparovek, G., 2013. Köppen's climate classification map for Brazil. Meteorol. Zeitschrift 22, 711-728. https://doi.org/10.1127/0941-2948/2013/0507

Atanassova, J.R., 2007. Pollen deposition in moss polsters and pollen traps in the Central Stara Planina Mts (2002-2005). Phytol. Balc. 13, 223-228.

Barlow, J., Gardner, T.A., Lees, A.C., Parry, L., Peres, C.A., 2012. How pristine are tropical forests? An ecological perspective on the pre-Columbian human footprint in Amazonia and implications for contemporary conservation. Biol. Conserv. 151, 45-49.

https://doi.org/10.1016/j.biocon.2011.10.013

Behling, H., 2007. Late Quaternary vegetation, fire and climate dynamics of Serra do Aracatuba in the Atlantic coastal mountains of Parana State, southern Brazil. Veg. Hist. Archaeobot. 16, 7785. https://doi.org/10.1007/s00334-006-0078-2

Behling, H., 2002. South and southeast Brazilian grasslands during Late Quaternary times: A synthesis. Palaeogeogr. Palaeoclimatol. Palaeoecol. 177, 19-27. https://doi.org/10.1016/S0031-0182(01)00349-2

Behling, H., 1997a. Late Quaternary vegetation, climate and fire history of the Araucaria forest and campos region from Serra Campos Gerais, Paraná State (South Brazil). Rev. Palaeobot. Palynol. 97, 109-121. https://doi.org/10.1016/S0034-6667(96)00065-6

Behling, H., 1997b. Late Quaternary vegetation, climate and fire history from the tropical mountain region of Morro de Itapeva, SE Brazil. Palaeogeogr. Palaeoclimatol. Palaeoecol. 129, 407-422. https://doi.org/10.1016/S0031-0182(97)88177-1 
Behling, H., 1995. Investigations into the late Pleistocene and Holocene history of vegetation and climate in Santa Catarina (S Brazil). Veg. Hist. Archaeobot. 4, 127-152. https://doi.org/10.1007/BF00203932

Behling, H., 1993. Untersuchungen zur Spatpleistozänen und Holozänen Vegetations- und Klimageschichte der Tropischen Kustenwalder und der Araukarienwälder in Santa Catarina (Sudbrasilien). Diss. Bot. J. Cramer, Stuttgart, Germany.

Behling, H., Bauermann, S.G., Neves, P.C.P. das, 2001. Holocene environmental changes in the Sao Francisco de Paula region, southern Brazil. J. South Am. Earth Sci. 14, 631-639. https://doi.org/10.1016/S0895-9811(01)00040-2

Behling, H., de Oliveira, M.A.T., 2018. Evidence of a late glacial warming event and early Holocene cooling in the southern Brazilian coastal highlands. Quat. Res. 89, 90-102. https://doi.org/10.1017/qua.2017.87

Behling, H., Pillar, V.D., Bauermann, S.G., 2005. Late Quaternary grassland (Campos), gallery forest, fire and climate dynamics, studied by pollen, charcoal and multivariate analysis of the São Francisco de Assis core in western Rio Grande do Sul (southern Brazil). Rev. Palaeobot. Palynol. 133, 235-248. https://doi.org/10.1016/j.revpalbo.2004.10.004

Behling, H., Pillar, V.D., Orlóci, L., Bauermann, S.G., 2004. Late Quaternary Araucaria forest, grassland (Campos), fire and climate dynamics, studied by high-resolution pollen, charcoal and multivariate analysis of the Cambará do Sul core in southern Brazil. Palaeogeogr. Palaeoclimatol. Palaeoecol. 203, 277-297. https://doi.org/10.1016/S0031-0182(03)00687-4

Behling, H., Verissimo, N., Bauermann, S., Bordignon, S., Evaldt, A., 2016. Late Holocene Vegetation History and Early Evidence of Araucaria angustifolia in Caçapava do Sul in the Lowland Region 

of Rio Grande do Sul State, Southern Brazil. Brazilian Arch. Biol. Technol. 59. https://doi.org/10.1590/1678-4324-2016150264

Bergamin, R.S., 2017. Variação espacial e temporal de espécies arbóreas em florestas da Mata Atlântica: perspectivas sobre o efeito de mudanças climáticas e planejamento de conservação. Universidade Federal do Rio Grande do Sul.

Bernal, J.P., Cruz, F.W., Stríkis, N.M., Wang, X., Deininger, M., Catunda, M.C.A., Ortega-Obregón, C., Cheng, H., Edwards, R.L., Auler, A.S., 2016. High-resolution Holocene South American monsoon history recorded by a speleothem from Botuverá Cave, Brazil. Earth Planet. Sci. Lett. 450, 186196. https://doi.org/10.1016/j.epsl.2016.06.008

Bitencourt, A.L.V., Krauspenhar, P.M., 2006. Possible prehistoric anthropogenic effect on Araucaria angustifolia (Bert.) O. Kuntze expansion during the late Holocene. Rev. Bras. Paleontol. 9, 109116.

Bittencourt, J.V.M., Sebbenn, A.M., 2008. Pollen movement within a continuous forest of windpollinated Araucaria angustifolia, inferred from paternity and TwoGener analysis. Conserv. Genet. 9, 855-868. https://doi.org/10.1007/s10592-007-9411-2

Bittencourt, J.V.M., Sebbenn, A.M., 2007. Patterns of pollen and seed dispersal in a small, fragmented population of the wind-pollinated tree Araucaria angustifolia in southern Brazil. Heredity (Edinb). 99, 580-591. https://doi.org/10.1038/sj.hdy.6801019

Burn, M.J., Mayle, F.E., Killeen, T.J., 2010. Pollen-based differentiation of Amazonian rainforest communities and implications for lowland palaeoecology in tropical South America. Palaeogeogr. Palaeoclimatol. Palaeoecol. 295, 1-18. https://doi.org/10.1016/j.palaeo.2010.05.009 
Bush, M.B., 1995. Neotropical Plant Reproductive Strategies and Fossil Pollen Representation. Am. Nat. 145, 594-609. https://doi.org/10.1086/285757

Bush, M.B., Rivera, R., 1998. Pollen Dispersal and Representation in a Neotropical Rain Forest. Glob. Ecol. Biogeogr. Lett. 7, 379-392. https://doi.org/10.2307/2997685

Bush, M.B., Weng, C., 2007. Introducing a new (freeware) tool for palynology. J. Biogeogr. 34, 377380. https://doi.org/10.1111/j.1365-2699.2006.01645.x

Carson, J.F., Mayle, F.E., Whitney, B.S., Iriarte, J., Soto, J.D., 2016. Pre-Columbian ring ditch construction and land use on a "chocolate forest island" in the Bolivian Amazon. J. Quat. Sci. 31, 337-347. https://doi.org/10.1002/jqs.2835

Carvalho, M.M.X. de, Nodari, E.S., 2010. As fases da exploração madeireira na floresta com Araucária e os progressivos avanços da indústria madeireira sobre as florestas primárias ( 1870-1970 ), in: Simpósio Internacional de História Ambiental e Migrações. UFSC, Florianópolis, pp. 707-726.

Caseldine, C.J., 1989. Pollen assemblage-plant community relationships on the Storbreen glacier foreland, Jotunheimen Mountains, southern Norway. New Phytol. 111, 105-118. https://doi.org/10.1111/j.1469-8137.1989.tb04224.x

Chou, S.C., Lyra, A., Mourão, C., Dereczynski, C., Pilotto, I., Gomes, J., Bustamante, J., Tavares, P., Silva, A., Rodrigues, D., Campos, D., Chagas, D., Sueiro, G., Siqueira, G., Marengo, J., 2014. Assessment of Climate Change over South America under RCP 4.5 and 8.5 Downscaling Scenarios. Am. J. Clim. Chang. 03, 512-527. https://doi.org/10.4236/ajcc.2014.35043

Colinvaux, P., Oliveira, P.E. de, Moreno Patiño, J.E., 1999. Amazon pollen manual and atlas. Harwood Academic Publishers. 
Colombo, A.F., Joly, C.A., 2010. Brazilian Atlantic Forest lato sensu: the most ancient Brazilian forest, and a biodiversity hotspot, is highly threatened by climate change. Brazilian J. Biol. 70, 697-708. https://doi.org/10.1590/S1519-69842010000400002

Correa-Metrio, A., Dechnik, Y., Lozano-García, S., Caballero, M., 2014. Detrended correspondence analysis: A useful tool to quantify ecological changes from fossil data sets. Boletín la Soc. Geológica Mex. 66, 135-143.

Corteletti, R., 2012. Projeto Arqueológico Alto Canoas-Paraca. Um estudo da presença Jê no planalto catarinense. Universidade de São Paulo.

Corteletti, R., Dickau, R., DeBlasis, P., Iriarte, J., 2015. Revisiting the economy and mobility of southern proto-Jê (Taquara-Itararé) groups in the southern Brazilian highlands: Starch grain and phytoliths analyses from the Bonin site, Urubici, Brazil. J. Archaeol. Sci. 58, 46-61. https://doi.org/10.1016/j.jas.2015.03.017

Danieli-Silva, A., Varassin, I.G., 2013. Breeding system and thrips (Thysanoptera) pollination in the endangered tree Ocotea porosa (Lauraceae): Implications for conservation. Plant Species Biol. 28, 31-40. https://doi.org/10.1111/j.1442-1984.2011.00354.x

Davis, M.B., 1963. On the Theory of Pollen Analysis. Am. J. Sci. 261, 897-912.

de Deus, F.F., do Vale, V.S., Schiavini, I., Oliveira, P.E., 2014. Diversity of reproductive ecological groups in semideciduous seasonal forests. Biosci. J. 30, 1885-1902.

De Souza, J.G., Corteletti, R., Robinson, M., Iriarte, J., 2016a. The genesis of monuments: Resisting outsiders in the contested landscapes of southern Brazil. J. Anthropol. Archaeol. 41, 196-212. https://doi.org/10.1016/j.jaa.2016.01.003

De Souza, J.G., Robinson, M., Corteletti, R., C??rdenas, M.L., Wolf, S., Iriarte, J., Mayle, F., DeBlasis, 
P., 2016b. Understanding the chronology and occupation dynamics of oversized pit houses in the southern Brazilian highlands. PLoS One 11, 1-24.

https://doi.org/10.1371/journal.pone.0158127

dos Reis, M.S., Ladio, A., Peroni, N., 2014. Landscapes with Araucaria in South America: Evidence for a cultural dimension. Ecol. Soc. 19, 43. https://doi.org/10.5751/ES-06163-190243

Duarte, L.D.S., Bergamin, R.S., Marcilio-Silva, V., Seger, G.D.D.S., Marques, M.C.M., 2014. Phylobetadiversity among forest types in the Brazilian Atlantic Forest complex. PLoS One 9. https://doi.org/10.1371/journal.pone.0105043

Faegri, K., Iversen, J., 1989. Textbook of Pollen Analysis, 4th ed, Textbook of pollen analysis. John Wiley \& Sons Ltd., Chichester, UK.

Fernandes, R.C., Piovezana, L., 2015. The Kaingang perspectives on land and environmental rights in the south of Brazil. Ambient. Soc. 18, 111-128. https://doi.org/10.1590/18094422ASOCEx07V1822015en

Fichino, B.S., Pivello, V.R., Santos, R.F., 2017. Trade-offs among ecosystem services under different pinion harvesting intensities in Brazilian Araucaria Forests. Int. J. Biodivers. Sci. Ecosyst. Serv. Manag. 13, 139-149. https://doi.org/10.1080/21513732.2016.1275811

Forest, F., Moat, J., Baloch, E., Brummitt, N.A., Bachman, S.P., Ickert-Bond, S., Hollingsworth, P.M., Liston, A., Little, D.P., Mathews, S., Rai, H., Rydin, C., Stevenson, D.W., Thomas, P., Buerki, S., 2018. Gymnosperms on the EDGE. Sci. Rep. 8, 6053. https://doi.org/10.1038/s41598-018$24365-4$

Formento, S., Schorn, L.A., Alaor, R., Ramos, B., 2004. Dinâmica Estrutural Arbórea De Uma Floresta Ombrófila Mista Em Campo Belo Do Sul , Sc. Cerne 10, 196-212. 
Freitas, L., Sazima, M., 2006. Pollination Biology in a Tropical High-Altitude Grassland in Brazil: Interactions at the Community Level. Ann. Missouri Bot. Gard. 93, 465-516.

Garcia, M.J., De Oliveira, P.E., de Siqueira, E., Fernandes, R.S., 2004. A Holocene vegetational and climatic record from the Atlantic rainforest belt of coastal State of São Paulo, SE Brazil. Rev. Palaeobot. Palynol. 131, 181-199. https://doi.org/10.1016/j.revpalbo.2004.03.007

Gessert, S., Iriarte, J., Ríos, R.C., Behling, H., 2011. Late Holocene vegetation and environmental dynamics of the Araucaria forest region in Misiones Province, NE Argentina. Rev. Palaeobot. Palynol. 166, 29-37. https://doi.org/10.1016/j.revpalbo.2011.04.006

Gonçalves, E.T., Souza, A.F., 2014. Floristic variation in ecotonal areas: Patterns, determinants and biogeographic origins of subtropical forests in South America. Austral Ecol. 39, 122-134. https://doi.org/10.1111/aec.12051

Gosling, W.D., Mayle, F.E., Tate, N.J., Killeen, T.J., 2009. Differentiation between Neotropical rainforest, dry forest, and savannah ecosystems by their modern pollen spectra and implications for the fossil pollen record. Rev. Palaeobot. Palynol. 153, 70-85. https://doi.org/10.1016/j.revpalbo.2008.06.007

Gu, F., Zonneveld, K.A.F., Chiessi, C.M., Arz, H.W., Pätzold, J., Behling, H., 2017. Long-term vegetation, climate and ocean dynamics inferred from a 73,500 years old marine sediment core (GeoB2107-3) off southern Brazil. Quat. Sci. Rev. 172, 55-71. https://doi.org/10.1016/j.quascirev.2017.06.028

Hammer, $\varnothing$., Harper, D.A.T., Ryan, P.D., 2001. PAST: Paleontological Statistics Software Package for Education and Data Analysis. Palaeontol. Electron. 4, 1-9. https://doi.org/10.1016/j.bcp.2008.05.025 
Haselhorst, D.S., Moreno, J.E., Punyasena, S.W., 2013. Variability within the 10-Year Pollen Rain of a Seasonal Neotropical Forest and Its Implications for Paleoenvironmental and Phenological Research. PLoS One 8. https://doi.org/10.1371/journal.pone.0053485

Haverroth, M., 1997. Kaingang, um estudo etnobotânico: o uso e a classificação das plantas na Área Indígena Xapecó (oeste de SC). Universidade Federal de Santa Catarina.

Heineberg, M.R., 2014. Conhecimento e Uso das Plantas pelos Xokleng na TI Ibirama-Laklãnõ, Santa Catarina. Universidade Federal de Santa Catarina.

Henry, J., 1964. Jungle people: A Kaingáng tribe of the highlands of Brazil, 2nd ed. Random House, New York, NY.

Hermes, M.G., Köhler, A., 2006. The flower-visiting social wasps (Hymenoptera, Vespidae, Polistinae) in two areas of Rio Grande do Sul State, southern Brazil. Rev. Bras. Entomol. 50, 268-274. https://doi.org/10.1590/S0085-56262006000200008

Hicks, S., 1985. Modern pollen deposition records from Kuusamo, Finland. Grana 24, 167-184. https://doi.org/10.1080/00173138509431005

Hicks, S., 1977. Modern pollen rain in Finnish Lapland investigated by analysis of surface moss samples. New Phytol. 78, 715-734. https://doi.org/10.1111/j.1469-8137.1977.tb02176.x

Higuchi, P., Silva, A.C. da, Sousa-Ferreira, T., Souza, S.T. de, Pereira-Gomes, J., Silva, K.M. da, Santos, K.F. do, 2012. Floristic composition and phytogeography of the tree component of Araucaria Forest fragments in southern Brazil. Brazilian J. Bot. 35, 145-157. https://doi.org/10.1590/S1806-99592012000200004

Hill, M.O., Gauch, H.G., 1980. Detrended correspondence analysis: An improved ordination technique. Vegetatio 42, 47-58. https://doi.org/10.1007/BF00048870 
Hoffmann, K.D., 2011. Mito, história e alteridade entre os Xokleng. Tellus 11, 53-69.

Hooghiemstra, H., 1984. Vegetational and climatic history of the high plain of Bogota, Colombia: a continuous record of the last 3.5 million years, Dissertationes Botanicae. J. Cramer.

Hueck, K., 1966. Die Wälder Südamerikas: Ökologie, Zusammensetzung und wirtschaftliche Bedeutung. G. Fischer, Stuttgart.

Hueck, K., 1953. Distribuição e habitat natural do Pinheiro do Paraná (Araucaria angustifolia). Bol. da Fac. Filos. Ciências e Let. Univ. São Paulo. 10, 5-24. https://doi.org/10.11606/issn.23185988.v10i1p5-24

Imperatriz-Fonseca, V.L., Kleinert-Giovannini, A., Ramalho, M., 1989. Pollen Harvest by Eusocial Bees in a Non-Natural Community in Brazil. Source J. Trop. Ecol. 5, 239-242.

Iriarte, J., Behling, H., 2007. The expansion of Araucaria forest in the southern Brazilian highlands during the last 4000 years and its implications for the development of the Taquara/Itararé Tradition. Environ. Archaeol. 12, 115-127. https://doi.org/10.1179/174963107x226390

Iriarte, J., DeBlasis, P., De Souza, J.G., Corteletti, R., 2016. Emergent Complexity, Changing Landscapes, and Spheres of Interaction in Southeastern South America During the Middle and Late Holocene. J. Archaeol. Res. 1-63. https://doi.org/10.1007/s10814-016-9100-0

Iriarte, J., Moehlecke Copé, S., Fradley, M., Lockhart, J.J., Gillam, J.C., 2013. Sacred landscapes of the southern Brazilian highlands: Understanding southern proto-Je mound and enclosure complexes. J. Anthropol. Archaeol. 32, 74-96. https://doi.org/10.1016/j.jaa.2012.10.003

Jeske-Pieruschka, V., Behling, H., 2012. Palaeoenvironmental history of the Sao Francisco de Paula region in southern Brazil during the late Quaternary inferred from the Rincao das Cabritas core. The Holocene 22, 1251-1262. https://doi.org/10.1177/0959683611414930 
Jeske-Pieruschka, V., Fidelis, A., Bergamin, R.S., Vélez, E., Behling, H., 2010. Araucaria forest dynamics in relation to fire frequency in southern Brazil based on fossil and modern pollen data. Rev. Palaeobot. Palynol. 160, 53-65. https://doi.org/10.1016/j.revpalbo.2010.01.005

Jeske-Pieruschka, V., Pillar, V.D., de Oliveira, M.A.T., Behling, H., 2013. New insights into vegetation, climate and fire history of southern Brazil revealed by a 40,000 year environmental record from the State Park Serra do Tabuleiro. Veg. Hist. Archaeobot. 22, 299-314. https://doi.org/10.1007/s00334-012-0382-y

Juggins, S., 2016. C2 Software for Ecological and Palaeoecological Data Analysis and Visualisation.

Kent, M., Coker, P., 1992. Vegetation description and analysis : a practical approach. CRC Press.

Klein, R.M., 1978. Mapa fitogeográfico do Estado de Santa Catarina, Flora llustrada Catarinense. Herbário “Barbosa Rodrigues," Itajai.

Klein, R.M., 1975. Southern Brazilian phytogeographic features and the probable influence of upper Quaternary climatic changes in the floristic distribution. Bol. Parana. Geociências 33, 67-88.

Lacerda, A.E.B., 2016. Conservation strategies for Araucaria Forests in Southern Brazil: assessing current and alternative approaches. Biotropica 48, 537-544. https://doi.org/10.1111/btp.12317

Lauterjung, M.B., Bernardi, A.P., Montagna, T., Candido-Ribeiro, R., da Costa, N.C.F., Mantovani, A., dos Reis, M.S., 2018. Phylogeography of Brazilian pine (Araucaria angustifolia): integrative evidence for pre-Columbian anthropogenic dispersal. Tree Genet. Genomes 14, 36. https://doi.org/10.1007/s11295-018-1250-4

Ledru, M.-P., Mourguiart, P., Riccomini, C., 2009. Related changes in biodiversity, insolation and climate in the Atlantic rainforest since the last interglacial. Palaeogeogr. Palaeoclimatol. 
Legendre, P., Legendre, L., Legendre, L., Legendre, P., 2012. Numerical ecology. Elsevier.

Leite, P.F., Klein, R.M., 1990. Vegetação, in: Mesquita, O.V. (Ed.), Geografia Do Brasil — Região Sul 853 (Vol. 2). Instituto Brasileiro de Geografia e Estatística, Rio de Janeiro, pp. 113-150.

Leonhardt, A., Lorscheitter, M.L., 2010. The last 25,000 years in the Eastern Plateau of Southern 855 Brazil according to Alpes de Sao Francisco record. J. South Am. Earth Sci. 29, 454-463. Levis, C., Costa, F.R.C., Bongers, F., Peña-Claros, M., Clement, C.R., Junqueira, A.B., Neves, E.G., O.L., Guevara, J.E., Sabatier, D., Molino, J.-F., López, D.C., Mendoza, A.M., Pitman, N.C.A., Duque, A., Vargas, P.N., Zartman, C.E., Vasquez, R., Andrade, A., Camargo, J.L., Feldpausch, T.R., Laurance, S.G.W., Laurance, W.F., Killeen, T.J., Nascimento, H.E.M., Montero, J.C., Mostacedo, B., Amaral, I.L., Guimarães Vieira, I.C., Brienen, R., Castellanos, H., Terborgh, J., Carim, M. de J.V., Guimarães, J.R. da S., Coelho, L.D.S., Matos, F.D.D.A., Wittmann, F., Mogollón, H.F., Damasco, G., Dávila, N., García-Villacorta, R., Coronado, E.N.H., Emilio, T., Filho, D. de A.L., Schietti, J., Souza, P., Targhetta, N., Comiskey, J.A., Marimon, B.S., Marimon, B.-H., Neill, D., Alonso, A., Arroyo, L., Carvalho, F.A., de Souza, F.C., Dallmeier, F., Pansonato, M.P., Duivenvoorden, J.F., Fine, P.V.A., Stevenson, P.R., Araujo-Murakami, A., Aymard C., G.A., Baraloto, C., do Amaral, D.D., Engel, J., Henkel, T.W., Maas, P., Petronelli, P., Revilla, J.D.C., Stropp, J., Daly, D., Gribel, R., Paredes, M.R., Silveira, M., Thomas-Caesar, R., Baker, T.R., da Silva, N.F., Ferreira, L. V., Peres, C.A., Silman, M.R., Cerón, C., Valverde, F.C., Di Fiore, A., Jimenez, E.M., Mora, M.C.P., Toledo, M., Barbosa, E.M., Bonates, L.C. de M., Arboleda, N.C., Farias, E. de S., Fuentes, A., Guillaumet, J.-L., Jørgensen, P.M., Malhi, Y., de Andrade Miranda, 
I.P., Phillips, J.F., Prieto, A., Rudas, A., Ruschel, A.R., Silva, N., von Hildebrand, P., Vos, V.A., Zent, E.L., Zent, S., Cintra, B.B.L., Nascimento, M.T., Oliveira, A.A., Ramirez-Angulo, H., Ramos, J.F., Rivas, G., Schöngart, J., Sierra, R., Tirado, M., van der Heijden, G., Torre, E. V., Wang, O., Young, K.R., Baider, C., Cano, A., Farfan-Rios, W., Ferreira, C., Hoffman, B., Mendoza, C., Mesones, I., Torres-Lezama, A., Medina, M.N.U., van Andel, T.R., Villarroel, D., Zagt, R., Alexiades, M.N., Balslev, H., Garcia-Cabrera, K., Gonzales, T., Hernandez, L., HuamantupaChuquimaco, I., Manzatto, A.G., Milliken, W., Cuenca, W.P., Pansini, S., Pauletto, D., Arevalo, F.R., Reis, N.F.C., Sampaio, A.F., Giraldo, L.E.U., Sandoval, E.H.V., Gamarra, L.V., Vela, C.I.A., ter Steege, H., 2017. Persistent effects of pre-Columbian plant domestication on Amazonian forest composition. Science (80-. ). 355, 925-931. https://doi.org/10.1126/science.aal0157

Levis, C., Flores, B.M., Moreira, P.A., Luize, B.G., Alves, R.P., Franco-Moraes, J., Lins, J., Konings, E., Peña-Claros, M., Bongers, F., Costa, F.R.C., Clement, C.R., 2018. How People Domesticated Amazonian Forests. Front. Ecol. Evol. 5, 1-21. https://doi.org/10.3389/fevo.2017.00171

López-Sáez, J.A., Alba-Sánchez, F., López-Merino, L., Pérez-Díaz, S., 2010. Modern pollen analysis: a reliable tool for discriminating Quercus rotundifolia communities in Central Spain. Phytocoenologia 40, 57-72. https://doi.org/10.1127/0340-269X/2010/0040-0430

Loponte, D., Carbonera, M., Corriale, M.J., Acosta, A., 2016. Horticulturists and oxygen ecozones in the tropical and subtropical forests of Southeast South America. Environ. Archaeol. 22, 1-21. https://doi.org/10.1080/14614103.2016.1211382

Maçaneiro, J.P. DE, Gasper, A.L. DE, Galvão, F., Schorn, L.A., 2018. Dispersion and aggregation patterns of tree species in Araucaria Forest, Southern Brazil. An. Acad. Bras. Cienc. 90, 23972408. https://doi.org/10.1590/0001-3765201820170150 
McMichael, C.N.H., Matthews-Bird, F., Farfan-Rios, W., Feeley, K.J., 2017. Ancient human disturbances may be skewing our understanding of Amazonian forests. Proc. Natl. Acad. Sci. 114, 522-527. https://doi.org/10.1073/pnas.1614577114

Mello, A.J.M., Peroni, N., 2015. Cultural landscapes of the Araucaria Forests in the northern plateau of Santa Catarina, Brazil. J. Ethnobiol. Ethnomed. 11, 51. https://doi.org/10.1186/s13002-0150039-x

Métraux, A., 1946. The Caingang, in: Steward, J.H. (Ed.), Handbook of South American Indians. The Marginal Tribes. Smithsonian Institution, Washington (D.C.), pp. 445-475.

Meyer, L., Sevegnani, L., de Gasper, A.L., Schorn, L.A., Vibrans, A.C., Lingner, D.V., Sobral, M.G., Klemz, G., Schmitt, R., Anastacio Jr., C., Brogni, E., 2013. Fitossociologia do componente arbóreo/arbustivo da Floresta Ombrófila Mista no Estado de Santa Catarina, in: Vibrans, A.C., Sevegnani, L., Gasper, A.L. De, Lingner, D.V. (Eds.), Inventário Florístico Florestal de Santa Catarina Volume III - Floresta Ombrófila Mista. Edifurb, Blumenau, pp. 157-189.

Midgley, J., 1989. Pollen dispersal distances for a conifer canopy species in the Knysna Forest. South African J. Bot. 55, 662-663.

Montade, V., Diogo, I.J.S., Bremond, L., Favier, C., Costa, I.R. da, Ledru, M.P., Paradis, L., Martins, E.S.P.R., Burte, J., Silva, F.H.M., Verola, C.F., 2016. Pollen-based characterization of montane forest types in north-eastern Brazil. Rev. Palaeobot. Palynol. 234, 147-158. https://doi.org/10.1016/j.revpalbo.2016.07.003

Montalva, J., Dudley, L., Arroyo, M.K., Retamales, H., Abrahamovich, A.H., 2011. Geographic distribution and associated flora of native and introduced bumble bees (Bombus spp.) in Chile. J. Apic. Res. 50, 11-21. 
Mrotzek, A., Couwenberg, J., Theuerkauf, M., Joosten, H., 2017. MARCO POLO - A new and simple tool for pollen-based stand-scale vegetation reconstruction. The Holocene 27, 321-330. https://doi.org/10.1177/0959683616660171

Müller, S.C., Overbeck, G.E., Blanco, C.C., de Oliveira, J.M., Pillar, V.D., 2012. South Brazilian ForestGrassland Ecotones: Dynamics Affected by Climate, Disturbance, and Woody Species Traits, in: Myster, R.W. (Ed.), Ecotones Between Forest and Grassland. Springer New York, New York, NY, pp. 167-187. https://doi.org/10.1007/978-1-4614-3797-0_7

Myers, N., Mittermeier, R.A., Mittermeier, C.G., da Fonseca, G.A.B., Kent, J., 2000. Biodiversity hotspots for conservation priorities. Nature 403, 853-858. https://doi.org/10.1038/35002501

Negash, L., 2003. In situ fertility decline and provenance differences in the East African Yellow Wood (Podocarpus falcatus) measured through in vitro seed germination. For. Ecol. Manage. 174, 127-138. https://doi.org/10.1016/S0378-1127(02)00034-8

Neves, D.M., Dexter, K.G., Pennington, R.T., Valente, A.S.M., Bueno, M.L., Eisenlohr, P. V., Fontes, M.A.L., Miranda, P.L.S., Moreira, S.N., Rezende, V.L., Saiter, F.Z., Oliveira-Filho, A.T., 2017. Dissecting a biodiversity hotspot: The importance of environmentally marginal habitats in the Atlantic Forest Domain of South America. Divers. Distrib. 23, 898-909. https://doi.org/10.1111/ddi.12581

Noelli, F.S., 2000. A ocupação humana na Região Sul do Brasil: Arqueologia, debates e perspectivas 1872-2000. Rev. da Univ. da São Paulo 44, 218-269.

Noelli, F.S., De Souza, J.G., 2017. Novas perspectivas para a cartografia arqueológica Jê no Brasil meridional. Bol. do Mus. Para. Emilio Goeldi Ciencias Humanas. https://doi.org/10.1590/1981.81222017000100004 
Oksanen, J., Minchin, P.R., 1997. Instability of ordination results under changes in input data order: explanations and remedies. J. Veg. Sci. 8, 447-454. https://doi.org/10.2307/3237336

Oliveira-Filho, A.T., Budke, J.C., Jarenkow, J.A., Eisenlohr, P. V, Neves, D.R.M., 2014. Delving into the variations in tree species composition and richness across South American subtropical Atlantic and Pampean forests. J. Plant Ecol. 8, 242-260. https://doi.org/10.1093/jpe/rtt058

Otegui, M., Cocucci, A., 1999. Flower morphology and biology of Myrsine laetevirens, structural and evolutionary implications of anemophily in Myrsinaceae. Nord. J. Bot. 19, 71-85. https://doi.org/10.1111/j.1756-1051.1999.tb01904.x

Pardoe, H.S., 2006. Surface pollen deposition on glacier forelands in southern Norway I: local patterns of representation and source area at Storbreen, Jotunheimen. The Holocene 16, 1149-1161. https://doi.org/10.1177/0959683606069422

Pardoe, H.S., Giesecke, T., van der Knaap, W.O., Svitavská-Svobodová, H., Kvavadze, E. V., Panajiotidis, S., Gerasimidis, A., Pidek, I.A., Zimny, M., Święta-Musznicka, J., Latałowa, M., Noryśkiewicz, A.M., Bozilova, E., Tonkov, S., Filipova-Marinova, M. V., van Leeuwen, J.F.N., Kalnina, L., 2010. Comparing pollen spectra from modified Tauber traps and moss samples: examples from a selection of woodlands across Europe. Veg. Hist. Archaeobot. 19, 271-283. https://doi.org/10.1007/s00334-010-0258-y

Parsons, R.W., Prentice, I.C., 1981. Statistical approaches to R-values and the pollen - vegetation relationship. Rev. Palaeobot. Palynol. 32, 127-152. https://doi.org/10.1016/00346667(81)90001-4

Peterson, R.H., Gale, D., 1991. Fish species associations in riffle habitat of streams of varying size and acidity in New Brunswick and Nova Scotia. J. Fish Biol. 38, 859-871. 
R Core Team, 2017. R: a Language and Environment for Statistical Computing.

Reis, M.S., Montagna, T., Mattos, A.G., Filippon, S., Ladio, A.H., Marques, A. da C., Zechini, A.A.,

Rezende, V.L., Eisenlohr, P. V., Vibrans, A.C., de Oliveira-Filho, A.T., 2015. Humidity, low temperature extremes, and space influence floristic variation across an insightful gradient in the Subtropical Atlantic Forest. Plant Ecol. 216, 759-774. https://doi.org/10.1007/s11258-0150465-9

Ribeiro, M.C., Metzger, J.P., Martensen, A.C., Ponzoni, F.J., Hirota, M.M., 2009. The Brazilian Atlantic Forest: How much is left, and how is the remaining forest distributed? Implications for conservation. Biol. Conserv. 142, 1141-1153. https://doi.org/10.1016/j.biocon.2009.02.021

Robinson, M., De Souza, J.G., Maezumi, S.Y., Cárdenas, M., Pessenda, L., Prufer, K., Corteletti, R., Scunderlick, D., Mayle, F.E., De Blasis, P., Iriarte, J., 2018. Uncoupling human and climate drivers of late Holocene vegetation change in southern Brazil. Sci. Rep. 8, 7800. https://doi.org/10.1038/s41598-018-24429-5

Robinson, M., Iriarte, J., De Souza, J.G., Marozzi, O., Scheel-Ybert, R., 2017. Moiety specific wood selection in funerary ritual for the southern proto-Jê. J. Archaeol. Sci. Reports 11, 237-244. https://doi.org/10.1016/j.jasrep.2016.11.047

Rodrigues, J.M., Behling, H., Giesecke, T., 2016a. Holocene dynamics of vegetation change in southern and southeastern Brazil is consistent with climate forcing. Quat. Sci. Rev. 146, 54-65. 
Rodrigues, J.M., Behling, H., Giesecke, T., 2016b. Differentiating vegetation types from eastern South American ecosystems based on modern and subfossil pollen samples: evaluating modern analogues. Veg. Hist. Archaeobot. 25, 387-403. https://doi.org/10.1007/s00334-0160558-y

Roubik, D.W., Moreno, J.E., 1991. Pollen and spores of Barro Colorado Island (Panama), Monographs in Systematic Botany. Missouri Botanical Garden, St. Louis, MO, USA.

Scherer, C., Lorscheitter, M.L., 2014. Vegetation dynamics in the southern Brazilian highlands during the last millennia and the role of bogs in Araucaria forest formation. Quat. Int. 325, 3-12. https://doi.org/10.1016/j.quaint.2014.01.010

Schorn, L.A., de Gasper, A.L., Meyer, L., Vibrans, A.C., 2012. Síntese da estrutura dos remanescentes florestais em Santa Catarina, in: Vibrans, A.C., Sevegnani, L., de Gasper, A.L., Lingner, D.V. (Eds.), Inventário Florístico Florestal de Santa Catarina Volume I - Diversidade e Conservação Dos Remanescentes Florestais. Edifurb, Blumenau, pp. 125-140.

Sevegnani, L., Uhlmann, A., de Gasper, A.L., Vibrans, A.C., dos Santos, A.S., Verdi, M., drev, 2013. Estádios sucessionais da Floresta Ombrófila Mista em Santa Catarina, in: Vibrans, A.C., Sevegnani, L., de Gaspar, A.L., Lingner, D.V. (Eds.), Inventário Florístico Florestal de Santa Catarina Volume III - Floresta Ombrófila Mista. Edifurb, Blumenau, p. 440.

Sevegnani, L., Uhlmann, A., Gasper, A.L. de, Meyer, L., Vibrans, A.C., 2016. Climate affects the structure of mixed rain forest in southern sector of Atlantic domain in Brazil. Acta Oecologica 77, 109-117. https://doi.org/10.1016/j.actao.2016.10.002

Shepard, G., Ramirez, H., 2011. "Made in Brazil": Human Dispersal of the Brazil Nut (Bertholletia 
1007 Silva, S.B. da, 2002. Dualismo e cosmologia Kaingang: o xamã e o domínio da floresta. Horizontes Antropológicos 8, 189-209. https://doi.org/10.1590/S0104-71832002000200009

Silva, L.C.R., Anand, M., 2011. Mechanisms of Araucaria (Atlantic) Forest Expansion into Southern Brazilian Grasslands. Ecosystems 14, 1354-1371. https://doi.org/10.1007/s10021-011-9486-y

Souza, L.A. de, Moscheta, I.S., 2000. Morfo-anatomia e aspectos da biologia floral de Nectandra megapotamica (Spreng.) Mez (Lauraceae). Acta Bot. Brasilica 14, 15-25. https://doi.org/10.1590/S0102-33062000000100003

Sugita, S., 2007a. Theory of quantitative reconstruction of vegetation I: pollen from large sites REVEALS regional vegetation composition. The Holocene 17, 229-241. https://doi.org/10.1177/0959683607075837

Sugita, S., 2007b. Theory of quantitative reconstruction of vegetation II: all you need is LOVE. The 1019 Thomas, P., 2013. Araucaria angustifolia [WWW Document]. IUCN Red List Threat. Species. Holocene 17, 243-257. https://doi.org/10.1177/0959683607075838

Tomlinson, P.B., 1974. Breeding Mechanisms in Trees Native to Tropical Florida - a Morphological 1023 Tonkov, S., Hicks, S., Bozilova, E., Atanassova, J., 2001. Pollen monitoring in the central Rila Mountains, Southwestern Bulgaria: comparisons between pollen traps and surface samples for the period 1993-1999. Rev. Palaeobot. Palynol. 117, 167-182. https://doi.org/10.1016/S0034- 
Urban, G., 1985. Interpretations of Inter-Cultural Contact: The Shokleng and Brazilian National Society 1914-1915. Ethnohistory 32, 224-244. https://doi.org/10.2307/481922

Vibrans, A.C., Sevegnani, L., Lingner, D.V., de Gasper, A.L., Sabbagh, S., 2010. Inventário florístico florestal de Santa Catarina (IFFSC): aspectos metodológicos e operacionais. Pesqui. Florest. Bras. 30, 291-302. https://doi.org/10.4336/2010.pfb.64.291

Viera, F. V., Fonseca, R.S., Araújo, L.M. de, 2012. Floração, Polinização e Sistemas Reprodutivos em Florestas Tropicais, in: Martins, S.V. (Ed.), Ecologia de Florestas Tropicais Do Brasil. Universidade Federal de Viçosa, Viçosa, pp. 53-84.

Whitehead, D.R., 1983. Wind pollination: some ecological and evolutionary perspectives, in: Real, L. (Ed.), Pollination Biology. Academic Press, Inc., Orlando, pp. 97-108.

Whitney, B.S., Smallman, T.L., Mitchard, E.T., Carson, J.F., Mayle, F.E., Bunting, M.J., 2019. Constraining pollen-based estimates of forest cover in the Amazon: A simulation approach. The Holocene 29, 262-270. https://doi.org/10.1177/0959683618810394

Wilms, W., Wendel, L., Zillikens, A., Blochtein, B., Engels, W., 1997. Bees and Other Insects Recorded on Flowering Trees in a Subtropical Araucaria Forest in Southern Brazil. Stud. Neotrop. Fauna Environ. 32, 220-226. https://doi.org/10.1080/01650521.1997.11432425doi.org/10.1080/01650521.1997.11432425

Wilson, V.R., Owens, J.N., 1999. The Reproductive Biology of Totara (Podocarpus totara) (Podocarpaceae). Ann. Bot. 83, 401-411.

Wrege, M.S., Higa, R.C. V., Miranda Britez, R., Cordeiro Garrastazu, M., de Sousa, V.A., Caramori, P.H., Radin, B., Braga, H.J., 2009. Climate Change and Conservation of Araucaria angustifolia in Brazil. Unasylva 60, 30-33. 
1049 Zeller, R.H., 2010. PLANO DE MANEJO: RESERVA PARTICULAR DO PATRIMÔNIO NATURAL EMILIO 1050 EINSFELD FILHO, SANTA CATARINA. Campo Belo do Sul.

1051

1052

1053 
1055 Figure 1: Map of forest plot locations; numbers refer to plot codes (see Table 1 below). Plot colours:

1056 Cyan: riverine; Olive: slope; Black: rock outcrop; Purple: open understorey; Orange: closed 1057 understorey; Red: disturbed.

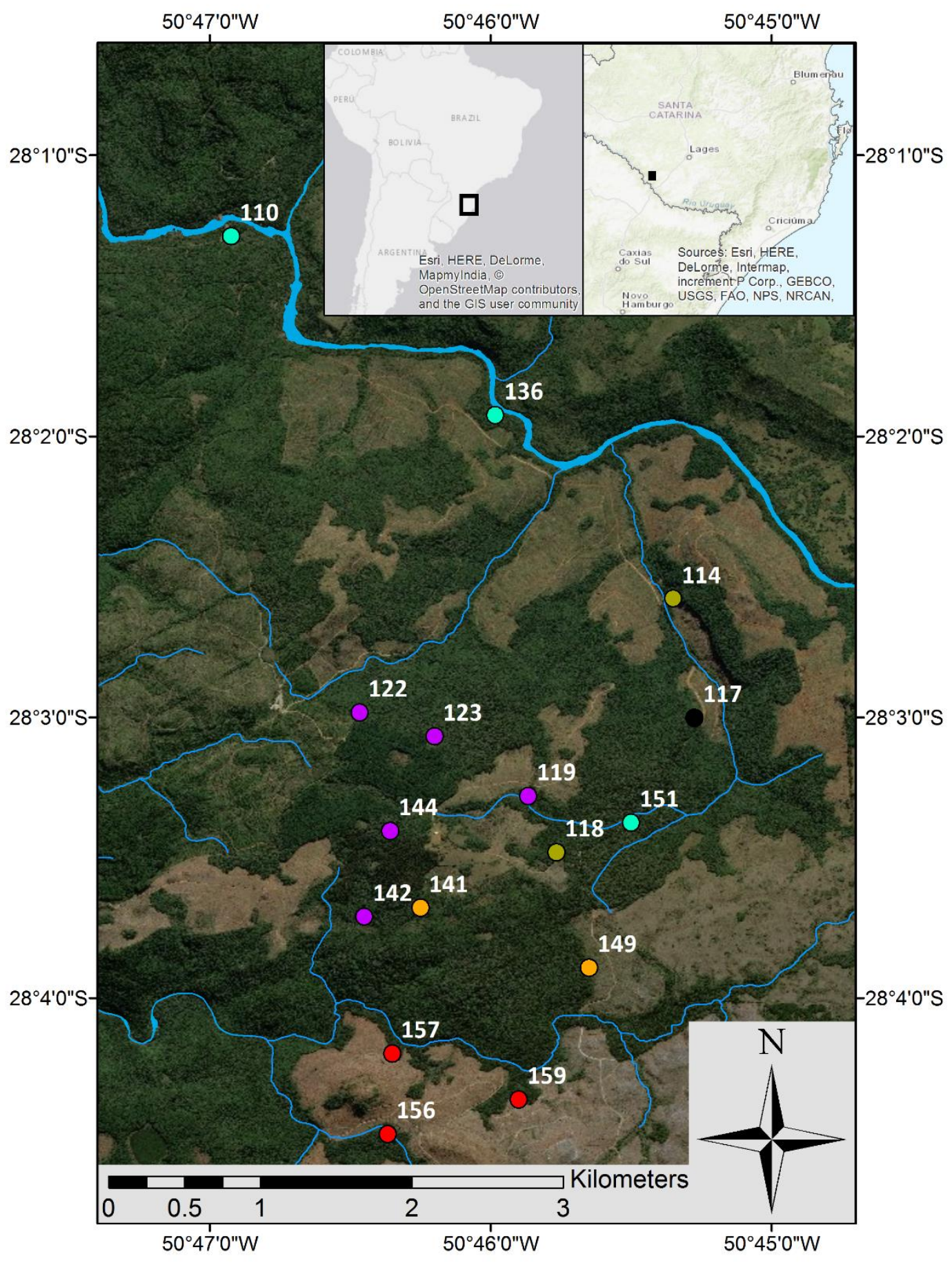


1059 Figure 2: Relative abundance (\%) of selected tree

1060

1061

cluster analysis and DCA are indicated with an asterisk.

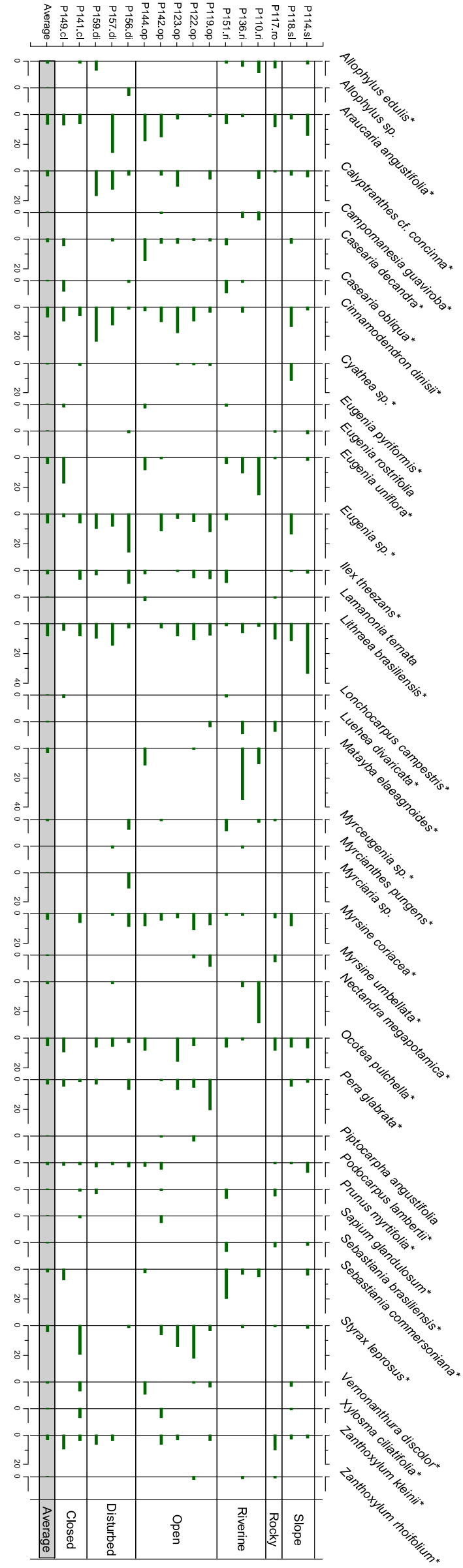


Figure 3: Relative Coverage Values (RCVs, \%) of selected

1064 tree species in the vegetation survey. 'Ave. (all)' $=$ sum of

1065 RCVs/total number of plots; 'Ave. (present)' = sum of

1066 RCVs/number of plots in which taxon was present.
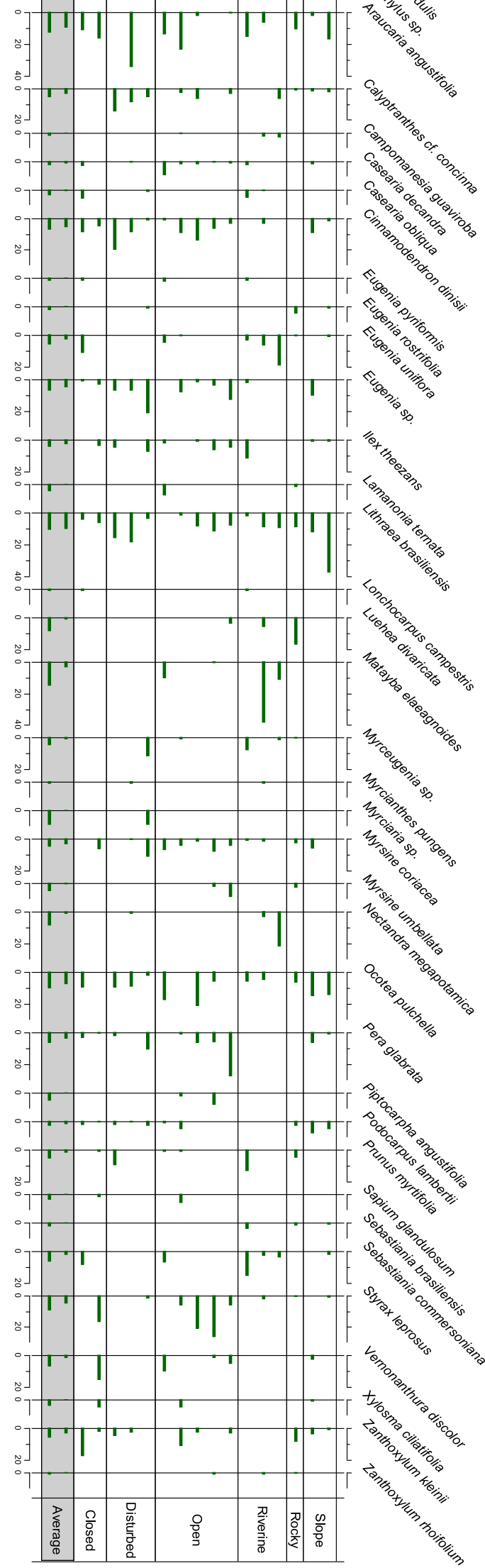


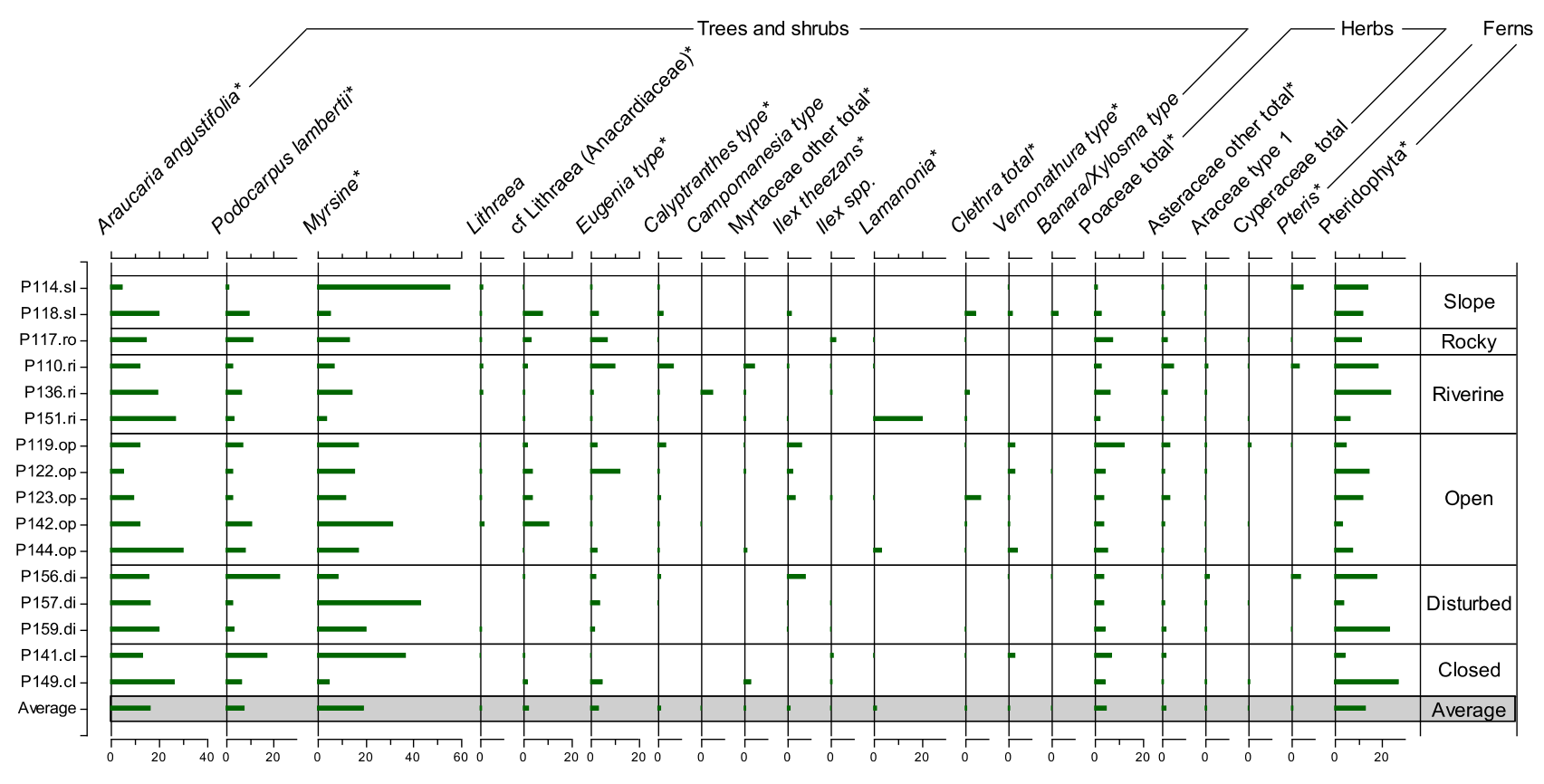


1072 Figure 5: Cluster analyses (left; $a, c$ ) and DCAs (right; b, d) of plots by vegetation (top; $a, b$ ) and 1073 pollen (bottom; $c$, d) taxa found in $\geq 2$ plots at $\geq 2 \%$ abundance. In the DCAs, convex hulls are 1074 delimited for structural categories containing three or more plots. Plot types are identified by 1075 colour and two-letter code (op: open; cl: closed; ri: riverine; di: disturbed; ro: rock; sl: slope; see 1076 Table 1).
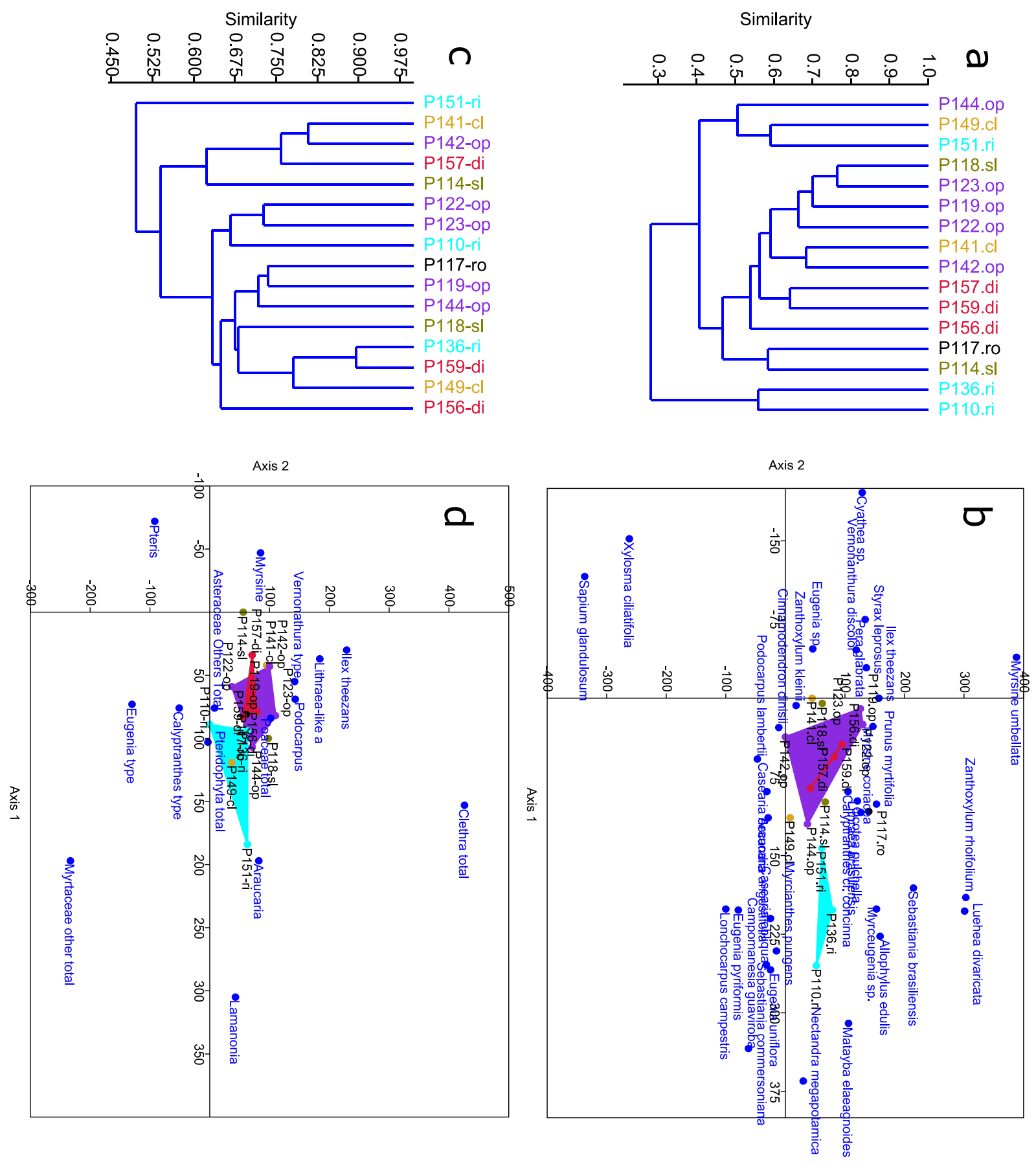

values (see section 3.4).

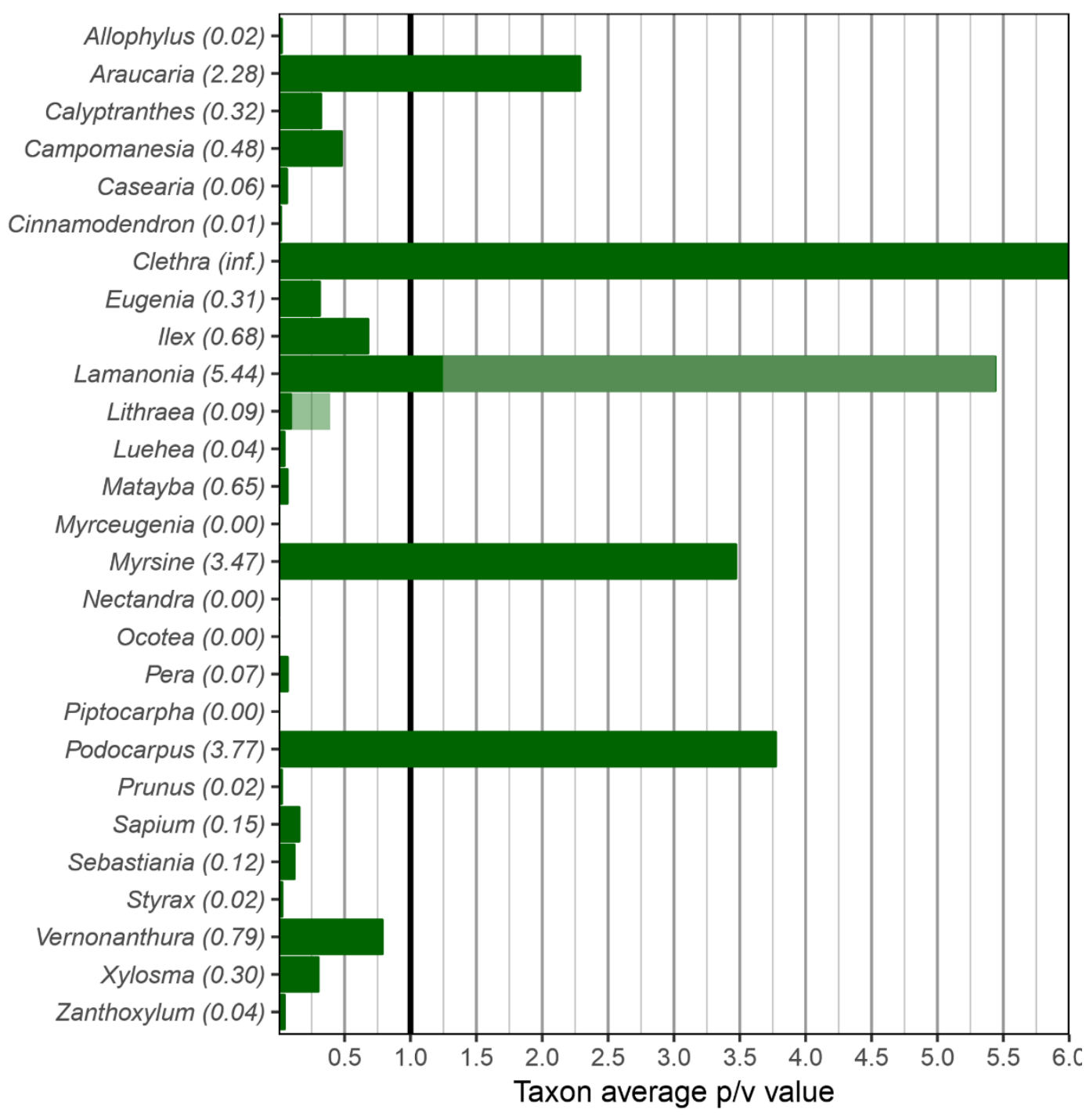


Figure 7: Pollen-vegetation abundance differentials (square-root transformed) for selected genera.

1083 Positive values denote plots where a taxon's pollen was more abundant than its vegetation; negative values reflect vegetation being more abundant than pollen. Blank cells denote plots where 1085 a taxon was absent from both pollen and vegetation data.

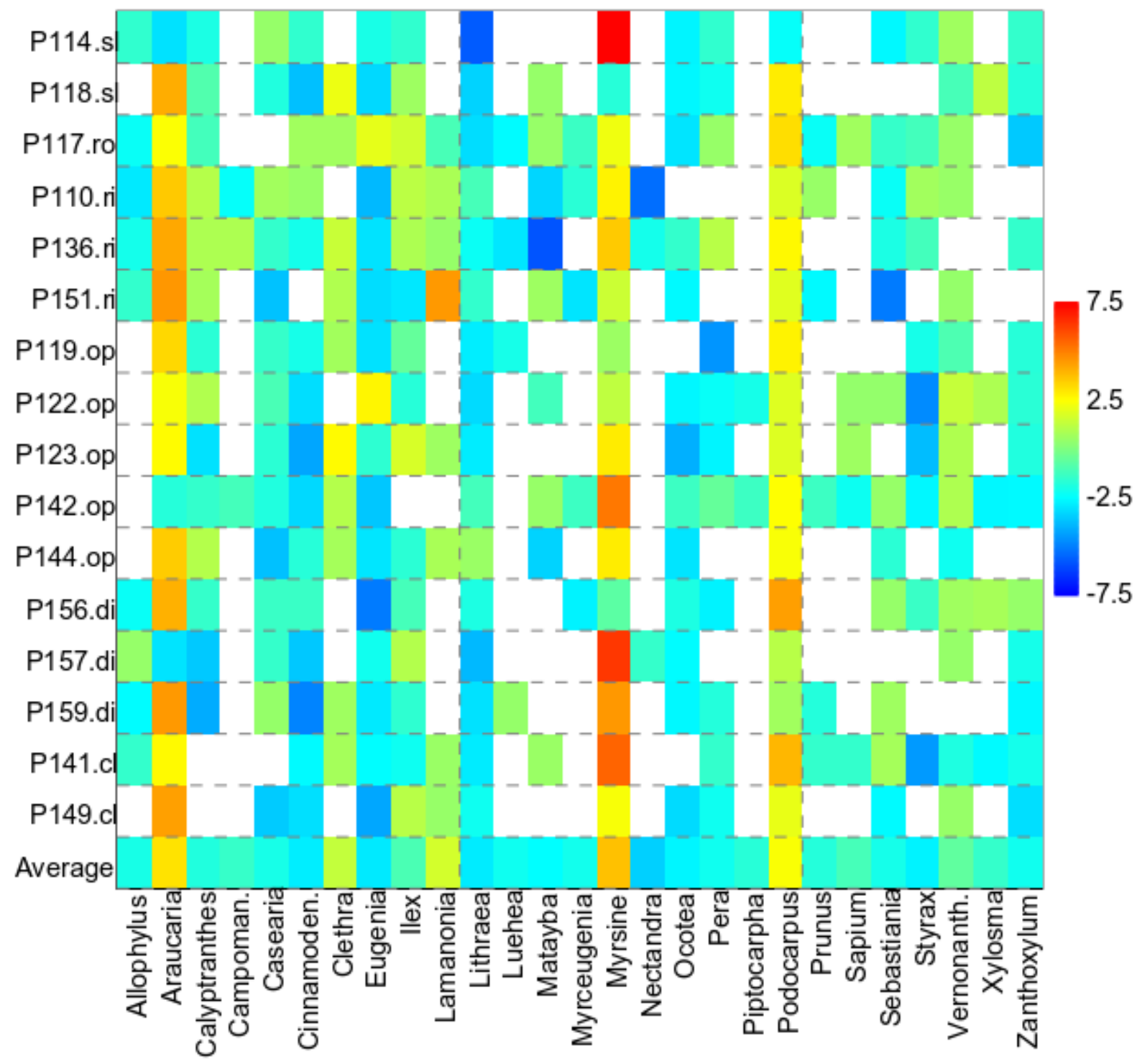

